\title{
Gases as Biological Messengers: Nitric Oxide and Carbon Monoxide in the Brain
}

\author{
Ted M. Dawson ${ }^{1,2}$ and Solomon H. Snyder ${ }^{1,3,4}$ \\ Departments of ${ }^{1}$ Neuroscience, ${ }^{2}$ Neurology, ${ }^{3}$ Pharmacology and Molecular Sciences, and ${ }^{4}$ Psychiatry and Behavioral \\ Sciences, Johns Hopkins University School of Medicine, Baltimore, Maryland 21205
}

The discovery of the role of nitric oxide (NO) in the nervous system has radically altered our thinking about synaptic transmission. Although there is considerable evidence that NO functions as a neurotransmitter, it is an unusual transmitter, in that it is a labile free-radical gas that is not stored in synaptic vesicles. NO is synthesized by NO synthase (NOS) from L- arginine, and simply diffuses from nerve terminals, as opposed to the exocytosis by which conventional neurotransmitters are released. NO does not undergo reversible interactions with receptors, as do the conventional neurotransmitters, but forms covalent linkages with several potential targets, which include enzymes such as guanylyl cyclase $(\mathrm{GC})$ and other protein or nonprotein molecules. The action of conventional neurotransmitters is terminated by presynaptic reuptake or enzymatic degradation, whereas the action of NO is presumably terminated by diffusion away from its targets, as well by forming covalent linkages to the superoxide anion or scavenger proteins.

\section{NO as a Biological Messenger}

It was long believed that the biosynthesis of nitrogen oxides was an exclusive function of microorganisms, which are well known for their oxidative (nitrification) or reductive (denitrification) pathways. However, as early as 1916 , it was noted that mammals secrete more nitrate in their urine than was present in their diets. Despite these initial observations, it was not until the early 1980 s that nitrogen oxides were established as normal byproducts of mammalian metabolism (Green et al., 1981a,b). Metabolites of NO increase dramatically during infection in humans as well as laboratory animals. The cytostatic and respiration-inhibiting effects of activated macrophages are dependent upon L-arginine, whose guanidino nitrogen is necessary to generate oxides of nitrogen. Analogs of L-arginine substituted on one or both of the guanidino nitrogens block macrophage cytotoxicity in a stereospecific manner, and the production of nitrite and nitrate by activated macrophages is blocked by these same analogs. Nitrites and nitrates cannot replicate the cytotoxicity of activated macrophages by themselves. However, NO

T.M.D. is supported by grants from the American Academy of Neurology and USPHS NIH CIDA NS-01578. S.H.S. is supported by USPHS Grants MH-18501, DA-00266, and Research Scientist Development Award DA-00074.

Correspondence should be addressed to Solomon H. Snyder, Department of Neuroscience, Johns Hopkins University School of Medicine, 725 North Wolfe Street, Baltimore, MD 21205.

Copyright (c) 1994 Society for Neuroscience $0270-6474 / 94 / 145147-13 \$ 05.00 / 0$ closely mimics macrophage mediated cytotoxicity, while scavengers of NO block its cytotoxic effect. Thus, it has been inferred that NO is the cytotoxic agent of activated macrophages (Hibbs et al., 1987; Stuehr et al., 1989).

Attempts to elucidate the vasodilatory effects of nitroglycerin and other organic nitrates (Arnold et al., 1977; Ignarro et al., 1981), and the role of endothelial cells in ACh-mediated relaxation of vascular muscle (Furchgott and Zawadzki, 1980), led to the discovery that NO is the primary endogenous vasodilator released from vascular endothelium (Ignarro et al., 1987; Palmer et al., 1987). Besides playing a role as a cytotoxic molecule of activated macrophages and relaxer of smooth muscle, NO also functions in the nervous system. For instance, cultured cerebellar granule cells release NO after exposure to glutamate analogs (Garthwaite et al., 1988). Additionally, NO appears to be a neuromodulator or neurotransmitter because NOS inhibitors, such as nitroarginine and methylarginine, block stimulation of cGMP synthesis in brain slices by glutamate acting at NMDA receptors (Bredt and Snyder, 1989; Garthwaite et al., 1989) and block nonadrenergic noncholinergic (NANC) relaxation of intestinal smooth muscle (Bult et al., 1990; Boeckxstaens et al., 1991; Desai et al., 1991; Tottrup et al., 1991).

\section{NO Biosynthesis}

NO is formed directly from the guanidino nitrogen of $\mathrm{L}$-arginine by NOS through a process that consumes five electrons and results in the formation of $\mathrm{L}$-citrulline (Fig. 1). NOS is an unusual oxidative enzyme in that most other enzymes consume one or two electrons for similar functions. Attempts at the purification of NOS were initially unsuccessful, due to the rapid loss of enzymatic activity upon purification. The loss of NOS activity was eventually accounted for by separation from its necessary cofactor, calmodulin (Bredt and Snyder, 1990). Once it was recognized that NOS is a calmodulin-dependent enzyme, NOS could be purified to homogeneity from cerebellum (Bredt and Snyder, 1990). Soon thereafter, purified NOS could be isolated from a variety of other brain tissues in a variety of species (Mayer et al., 1990; Schmidt et al., 1991), as well as from macrophages (Hevel et al., 1991; Stuehr et al., 1991a; Yui et al., 1991; Evans et al., 1992) and endothelial tissue (Pollock et al., 1991).

NOS structure and function have been clarified by the molecular cloning of the cDNA for brain (Bredt et al., 199 lb; Nakane et al., 1993; Ogura et al., 1993), endothelial (Janssens 


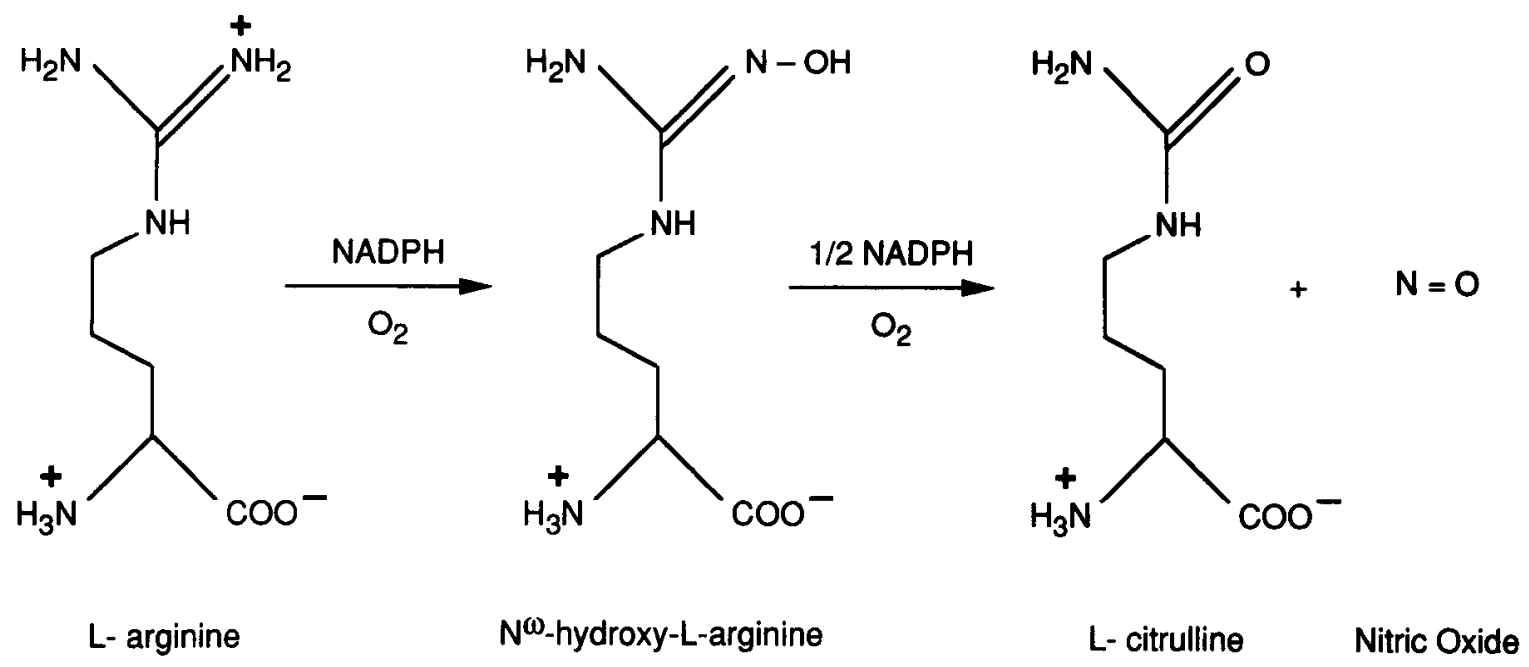

Figure 1. Biosynthesis of NO. L- Arginine is converted to NO in at least two successive steps of which a two-electron oxidation of L-arginine to $N$ - $\omega$-hydroxy-L-arginine is the first. This hydroxylation resembles the cytochrome P450 type of monooxygenation, utilizing one equivalent each of NADPH and $\mathrm{O}_{2}$ (Marletta, 1993). In the second step, $N$ - $\omega$-hydroxy-L-arginine is converted to NO and citrulline. The mechanism of this conversion is less well understood, but it utilizes 0.5 equivalents of NADPH and requires $\mathrm{O}_{2}$. Both steps require $\mathrm{Ca}^{2+}$ and calmodulin as activators and are accelerated by tetrahydrobiopterin, and blocked by CO (Stuehr et al., 1991b; White and Marletta, 1992).

et al., 1992; Lamas et al., 1992; Sessa et al., 1992), macrophage (Lowenstein et al., 1992; Lyons et al., 1992; Xie et al., 1992), and non-macrophage-inducible (Charles et al., 1993; Geller et al., 1993) NOS (Fig. 2). Alternative splicing of the mRNA for neuronal NOS was revealed by the cloning of mouse neuronal NOS. In mouse cerebellum $10 \%$ of the NOS mRNA has a 415 nucleotide deletion corresponding to nucleotides 1510-1824 (Ogura et al., 1993). Cloning of human neuronal NOS reveals a greater abundance of neuronal NOS mRNA in skeletal muscle than in brain, while rat skeletal muscle is almost devoid of neuronal NOS mRNA (Bredt et al., 1991b; Nakane et al., 1993). The human neuronal NOS is located on chromosome 12 (Nakane et al., 1993). Human endothelial NOS was mapped to chromosome 7 , the same chromosome that contains cytochrome P450 reductase (Marsden et al., 1993). The $5^{\prime}$ promoter region of the human endothelial genes contains AP-1, AP-2, NF-1 heavy metal, acute phase response shear stress, and sterol regulatory elements. The human inducible NOS genes map to chromosome 17 (Xu et al., 1993).

The molecular cloning data reveal the positions of recognition sites for NADPH, as well as for flavin mononucleotide (FMN) and flavin adenine dinucleotide (FAD) (Bredt et al., 199lb), which bind NOS stoichiometrically (Hevel et al., 1991; Mayer et al., 1991; Bredt et al., 1992; Schmidt et al., 1992b; Klatt et al., 1993). Cytochrome P-450 reductase (CPR) is the only other mammalian enzyme known to contain recognition sites for NADPH, as well as for both FMN and FAD (Fig. 2). The hepatic drug-scavenging cytochrome P-450 system utilizes CPR as its electron donor. CPR is $60 \%$ homologous at the amino acid level to the carboxyl-terminal half of NOS. This homology with CPR is shared by all NOS isoforms cloned and reflects the oxidative nature of NO biosynthesis. Early in evolution, NO formation presumably proceeded through donation of electrons by CPR, and at some later stage a fusion between $\mathrm{CPR}$ and the $\mathrm{N}$-terminal half of NOS occurred. Indeed, when the C-terminal and N-terminal halves of NOS are expressed separately, and mixed, NOS catalytic activity is obtained (D. S. Bredt and S. H. Snyder, unpublished observations).
NOS also uses tetrahydrobiopterin as an electron transferring cofactor (Kwon et al., 1989; Tayeh and Marletta, 1989; Mayer et al., 1991). The exact role of tctrahydrobiopterin is not clear, but it may facilitate L-arginine binding through the stabilization of the enzyme (Giovanelli et al., 1991; Hevel and Marletta, 1992; Marletta, 1993). Recently, NOS was found to contain heme, which reacts with $\mathrm{CO}$ to form a species absorbing at 445 $\mathrm{nm}$, indicating that NOS is a cytochrome P-450 enzyme (Klatt et al., 1992; McMillan et al., 1992; Stuehr and Ikeda-Saito, 1992; White and Marletta, 1992). CO inhibits purified NOS, which is consistent with the participation of a cytochrome P450-type heme in the reaction. Moreover, NO itself appears to interact with the enzyme's heme and inhibit its own formation, thus exerting feedback inhibition (Assreuy et al., 1993; Rengasamy and Johns, 1993). The mechanism of electron transfer is likely to be similar to that of the cytochrome P-450 enzymes, in that NADPH reduces FAD, which subsequently reduces FMN, which in turn transfers electrons to the ferric heme, promoting the interaction with molecular oxygen.

Some NOS enzymes are constitutive in the sense that their activation does not require new enzyme protein synthesis. For instance, the neuronal form of NOS, which is activated by glutamate neurotransmission acting on NMDA receptors, is clearly constitutive. Here, in a matter of seconds, the glutamate-induced increase in intracellular $\mathrm{Ca}^{2+}$ levels activates NOS via calmodulin. The endothelial form of NOS is also constitutive, being activated by increases in intracellular $\mathrm{Ca}^{2+}$ levels. Agonists such as ACh or bradykinin acting at muscarinic or bradykinin receptors, respectively, on endothelial cells, activate the phosphoinositide cycle to generate $\mathrm{Ca}^{2+}$, which then stimulates NOS by binding calmodulin. Constitutive NOS enzymes account for the role of $\mathrm{NO}$ in mediating rapid events, such as neurotransmission and blood vessel dilatation.

Neuronal and endothelial forms of NOS are also inducible in the sense that in the response to certain stimuli, new enzyme protein synthesis occurs. In PC-12 cells, neuronal NOS is induced after $8 \mathrm{~d}$ of exposure to NGF (Hirsch et al., 1993). In addition, injury of the spinal cord evokes the induction of neu- 


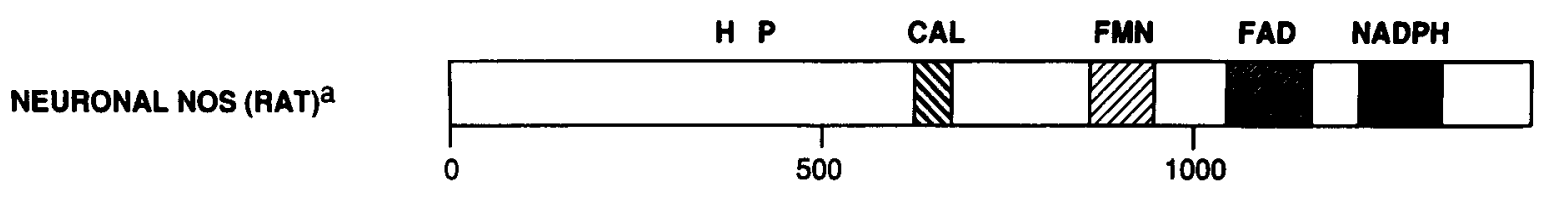

ENDOTHELIAL NOS (BOVINE) ${ }^{\mathrm{b}}$

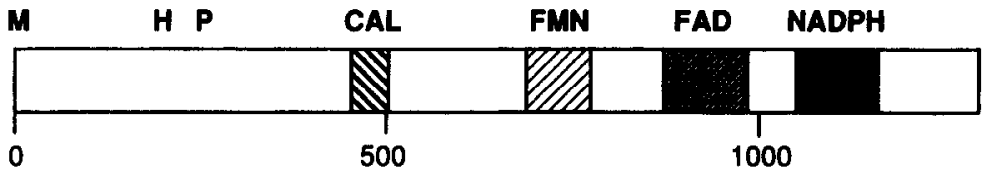

MACROPHAGE NOS (MURINE)

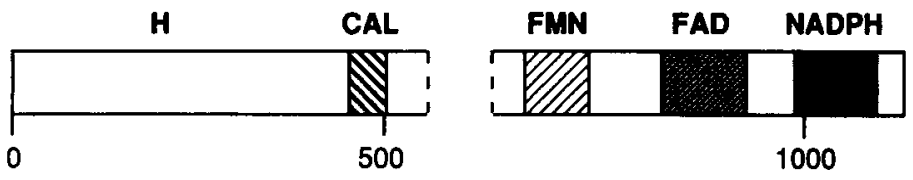

HEPATIC NOS (HUMAN) ${ }^{d}$

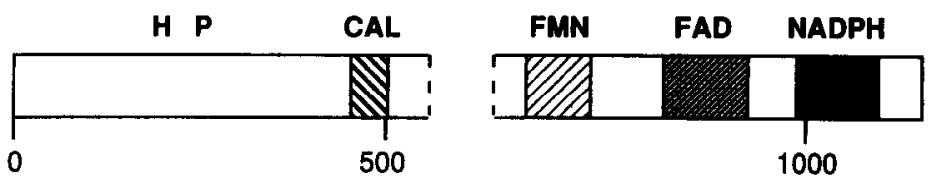

CYTOCHROME P $_{450}$ REDUCTASE

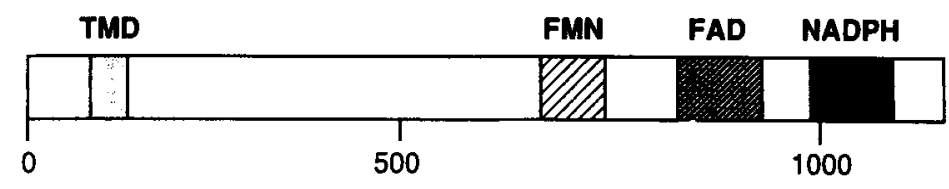

Figure 2. Sequence homologies of molecular isoforms of NOS. All NOS enzymes cloned thus far have homologous regions to cytochrome P450 reductase and substrate binding sites that reflect the oxidative mechanism of NO biosynthesis. Consensus binding sites for FAD, FMN, NADPH, and calmodulin are conserved for all NOS enzymes cloned. Protein kinase A phosphorylation sites (labeled $P$ ) are conserved between the brain and endothelial forms. The human hepatic NOS contains three consensus sequences for protein kinase A (labeled $P$ ). Abbreviations: $P$, consensus sequence for phosphorylation by cAMP-dependent protein kinase; $C A L$, calmodulin binding site; $F M N$, flavin mononucleotide; $F A D$, flavin adenine dinucleotide; $H$, heme binding site; $N A D P H$, reduced form of nicotinamide adenine dinucleotide phosphate; $T M D$, transmembrane domain, $M$, myristoylation site. $a$. Bredt et al., 1991b; $b$, Janssens et al., 1992; Lamas et al., 1992; Sessa et al., 1992; $c$, Lowenstein et al., 1992; Lyons et al., 1992; Xie et al., 1992; $d$, Charles et al., 1993; Geller et al., 1993; $e$, Porter and Kasper, 1985.

ronal NOS mRNA in dorsal root ganglia (Verge et al., 1992) and the appearance of NOS-immunoreactive neurons (Wu et al., 1993), which stain for NADPH-diaphorase (Solodkin et al., 1992; Vizzard et al., 1993; Wu, 1993). Neuronal NOS is also differentially regulated in the rat and mouse developing nervous system. Though absent from dividing cclls, NOS is coexpressed with the earliest markers of neuronal differentiation. Neuronal NOS activity peaks at gestational day 16 , is nearly absent at birth and reappears at postnatal day 10 (Bredt and Snyder, unpublished observations). NO may regulate process outgrowth and remodeling during neuronal development that occurs at least, in part, through modulation of protein fatty acylation in growth cones (Douglas et al., 1993). Thus, NO may be important in activity-dependent remodeling of axon terminals during development. Endothelial cells also express an increased level of endothelial NOS following middle cerebral artery occlusion ( $\mathrm{Z}$. G. Zhang et al., 1993).

Normally macrophages do not contain detectable levels of NOS protein. Both in vivo and in vitro stimulation with a variety of cytokines, such as $\gamma$-interferon and lipopolysaccharide (LPS), elicit new NOS protein synthesis over $2-4 \mathrm{hr}$. The inducible NOS of macrophages produces large quantities of NO, which mediate destruction of microorganisms and tumors and may also lead to pathologic tissue damage. Inducible NOS of macrophages is not stimulated by $\mathrm{Ca}^{2+}$, but surprisingly, inducible
NOS enzymes do possess calmodulin recognition sites (Fig. 2). Calmodulin is very tightly bound to inducible macrophage NOS (Cho et al., 1992), with the binding unaffected by $\mathrm{Ca}^{2+}$, whereas calmodulin cannot bind to neuronal NOS unless $\mathrm{Ca}^{2+}$ is present. Thus, calmodulin may be considered a protein subunit of inducible macrophage NOS, which accounts for its resistance to $\mathrm{Ca}^{2+}$ activation (Nathan, 1992). Since the demonstration that macrophages contain an inducible form of NOS, inducible NOS activity has been found also following endotoxin treatment in a diversity of tissues lacking macrophages (Nathan, 1992). Brain astrocytes and microglia possess an inducible NOS, which is induced by a variety of cytokines (Murphy et al., 1993). Induction of inducible NOS in astrocytes and microglia may account for the tissue damage associated with a variety of neurologic disorders (Murphy et al., 1993). Astrocytes and microglia also possess a $\mathrm{Ca}^{2+}$-dependent NOS which is constitutively expressed (Murphy et al., 1993). The inducible NOS of human hepatocytes (Geller et al., 1993) and chrondocytes (Charles et al., 1993) has recently been cloned and might represent the prototype for a non-macrophage-inducible NOS. The ubiquitous distribution of this type of inducible NOS may reflect a primitive sort of immune response to invading microbial pathogens.

Consensus sequences for phosphorylation by cAMP-dependent protein kinase are evident in neuronal, endothelial, and 
hepatic inducible NOS enzymes, but not in macrophage NOS (Fig. 2). Consensus sequences for phosphorylation by other kinases have not been characterized in detail. Biochemical studies indicate that neuronal NOS can be phosphorylated by protein kinase $\mathrm{C}, \mathrm{Ca}^{2+} /$ calmodulin-dependent protein kinase, cAMPdependent protein kinase, and cGMP-dependent protein kinase (Brüne and Lapetina, 1991; Nakane et al., 1991; Bredt et al., 1992). Phosphorylation by all these enzymes decreases NOS catalytic activity (J. L. Dinerman, J. P. Steiner, T. M. Dawson, and S. H. Snyder, unpublished observations). NOS is also a calcineurin substrate, with calcineurin dephosphorylating NOS and increasing its catalytic activity (T. M. Dawson et al., 1993). Multiple levels of constitutive neuronal NOS regulation are thus possible by phosphorylation. $\mathrm{Ca}^{2+} /$ calmodulin can directly activate NOS and also increase its catalytic activity by activation of calcineurin to dephosphorylate it. But, $\mathrm{Ca}^{2+} /$ calmodulin can activate $\mathrm{Ca}^{2+} /$ calmodulin-dependent protein kinase to enhance phosphorylation of NOS and hence decrease its catalytic activity. In conjunction with lipids $\mathrm{Ca}^{2+}$ can activate protein kinase $\mathrm{C}$, whose phosphorylation of NOS would decrease its activity. Activation of guanylyl cyclase by NO to form cGMP could act as a negative feedback mechanism, in that increased levels of cGMP would activate a cGMP-dependent protein kinase whose phosphorylation of NOS would decrease its activity.

One would expect regulation of inducible NOS to occur at the level of gene transcription and enzyme protein synthesis. Characterization of the promotor region of the gene for macrophage-inducible NOS (macNOS) reveals a complex pattern of regulation (Lowenstein et al., 1993; Xie et al., 1993). LPS and $\gamma$-interferon responsive elements occur in two distinct regulatory sites with LPS directly stimulating macNOS expression while $\gamma$-interferon acts only in the presence of LPS. Upstream from the transcription start site there appear to be two distinct regulatory regions upstream of the TATA box. Region 1, which lies about 50-200 base pairs upstream of the start site, contains LPS-related response elements, such as the binding site for NFIL6 and the binding site for NFkappaB (NFKB), indicating that this region regulates the LPS-induced expression of macNOS. Region 2, which lies about 900-1000 base pairs upstream of the start site, contains motifs for $\gamma$-interferon-related transcription factors. Activation of region 2 provides a further 10 -fold increase above the 75 -fold increase in NOS expression provided by activation of rcgion 1 , but does not in itself directly regulate NOS expression. This complex organization of the macNOS promotor may explain some important aspects of inflammation. For instance, in sepsis, gram negative bacteria release LPS, which circulates throughout the body and sets off an inflammatory response. $\gamma$-Interferon, in contrast, is released locally by infiltrating lymphocytes and serves to augment the inflammatory response, by priming the macrophages for a maximal LPS induction of NOS. Thus, maximal production of NO is restricted to those macrophages that are in close proximity to the site of cellular insult, thereby minimizing damage to adjacent healthy tissue.

Neuronal NOS has a molecular weight of $160 \mathrm{kDa}$, whereas endothelial and macrophage NOS are about $130 \mathrm{kDa}$. All isoforms occur as dimers. Neuronal and macrophage NOS have been characterized as soluble proteins, but subcellular fractionation studies reveal that a significant amount of neuronal NOS is present in the particulate fraction (Hiki et al., 1993). The properties of neuronal NOS that facilitate incorporation in the particulate fraction are presently unclear, but could involve pro- tein modifications or interactions with novel binding proteins. In contrast, endothelial NOS is predominantly present in the particulate fraction. Molecular cloning of endothelial NOS reveals no obvious transmembrane spanning regions (Janssens et al., 1992b; Lamas et al., 1992; Sessa et al., 1992), but there is a consensus motif for $\mathrm{N}$-terminal myristoylation, whose $\mathrm{mu}$ tational deletion renders endothelial NOS soluble (Busconi and Michel, 1993). In addition, ${ }^{3} \mathrm{H}$-myristate is directly incorporated into endothelial NOS, and insertion of the myristoyl group into the plasma membrane presumably accounts for the enzyme's location in the particulate fraction (Busconi and Michel, 1993).

\section{Neuronal Function and NO}

Immunohistochemical staining with an antibody raised against the purified neuronal NOS antigen showed that brain neuronal NOS occurs only in neurons. NOS neurons comprise only about $1-2 \%$ of all the cells in many areas, such as the cerebral cortex, the hippocampal formation, and corpus striatum. NOS neurons are not displayed in an obvious pattern and exhibit morphologic properties of medium to large aspiny neurons that are scattered throughout the same regions. In the hippocampus, none of the pyramidal cells contain neuronal NOS (Bredt et al., 1991a; Schmidt et al., 1992a; Dinerman et al., 1994), but there are numerous NOS interneurons with extensive processes throughout the CAl region of the hippocampus. Granule cells of the dentate gyrus of the hippocampus, in contrast, have abundant ncuronal NOS. In the hypothalamus, NOS ncurons are cvident within the paraventricular magnocellular neurons as well as the supraoptic neurons that project to the posterior pituitary, which contains a dense plexus of NOS fibers. The midbrain contains a dense plexus of NOS neurons, fibers, and terminals within the superficial layers of the superior and inferior colliculi. NOS neurons are also abundant within the lateral dorsal tegmental and pedunculopontine tegmental nuclei, which innervate several thalamic nuclei (Bredt et al., 1990, 1991a).

In the cerebellum, NOS is present in granule cells and their parallel fiber axon terminals as well as basket cells, but not in Purkinje cells. Glutamate raises cGMP levels in the cerebellum through stimulation of NMDA receptors that are present on granule cell parallel fiber axon terminals and basket cells, which conceivably triggers the formation of NO that diffuses to the adjacent Purkinje cells to activate guanylyl cyclase. cGMP is sclectively concentrated in Purkinje cclls that reccive input from terminals of granule and basket cells. While NO clearly activates guanylyl cyclase in the cerebellum as well as other brain regions, this association may not be universal throughout the brain. If NO exclusively activated guanylate cyclase, then localizations of guanylyl cyclase and NOS should be closely similar. Since they differ markedly, NO probably influences other targets; alternatively, guanylyl cyclase may be the target for other transmitters besides NO.

There does not appear to be a specific pattern of neurotransmitter colocalization for NOS. In the cerebellum NOS occurs in glutaminergic granule cells as well as GABAergic basket cells. In the cerebral cortex, NOS neurons contain GABA, somatostatin, and neuropeptide Y (Vincent et al., 1983; T. M. Dawson et al., 1991). In the corpus striatum all NOS neurons stain for somatostatin and neuropeptide $Y$, while in the pedunculopontine tegmental nucleus of the brainstem, NOS neurons lack somatostatin and neuropeptide $\mathrm{Y}$, but stain for ChAT (T. M. Dawson et al., 1991). However, all NOS neurons stain for NADPH-diaphorase (T. M. Dawson et al., 1991; Hope et al., 
1991). NADPH-diaphorase reduces tetrazolium dyes, in the presence of NADPH but not NADH (Thomas and Pearse, 1961, 1964), resulting in a blue formazan precipitant. Transfection of cultured human kidney-293 cells, lacking NOS or diaphorase, with neuronal NOS CDNA produced cells that stain for both NADPH-diaphorase and NOS. NOS and NADPH-diaphorase staining in these cells occur in exactly the same proportion as neurons in the brain, establishing that NOS catalytic activity accounts for diaphorase staining (T. M. Dawson et al., 1991). In brain homogenates, most of the diaphorase activity is unrelated to NOS (Hope et al., 1991). However, in paraformaldehyde-fixed tissue, NADPH-diaphorase staining is coincident with NOS immunoreactivity in neurons (T. M. Dawson et al., 1991). The paraformaldehyde fixation presumably inactivates virtually all NADPH-dependent oxidative enzymes except NOS, enabling the NADPH-diaphorase stain to label NOS neurons selectively. NADPH-diaphorase/NOS-containing cells are unusual in that they are notably resistant to destruction in Huntington's and Alzheimer's disease, vascular stroke, and NMDA neurotoxicity (Ferrante et al., 1985; Koh et al., 1986; Koh and Choi, 1988; Uemura et al., 1990; Hyman et al., 1992).

What are the normal functions of NOS neurons? NO appears to influence neurotransmitter release. In several model systems, NOS inhibitors, such as nitroarginine, block the release of neurotransmitters (Dickie et al., 1992; Hanbauer et al., 1992; Lonart et al., 1992; Zhu and Luo, 1992). Release of ACh in response to depolarization, by increasing the extracellular potassium $\left(\mathrm{K}^{+}\right)$ concentration, is markedly enhanced after $8 \mathrm{~d}$ of NGF application (Hirsch et al., 1993) to cultured PC-12 cells. $\mathrm{K}^{+}$depolarization in cultured PC-12 cells after NGF treatment also elicited a marked enhancement of cGMP levels that was coincident with the marked enhancement of ACh release (Sandberg et al., 1989a,b). NOS accounts for the marked enhancement in ACh release and the accompanying increase in cGMP levels. Release of both ACh and dopamine from NGF-treated PC- 12 cells is blocked by NOS inhibitors and reversed by excess L-arginine (Hirsch et al., 1993). Furthermore, in brain synaptosomes the release of neurotransmitter invoked by stimulation of NMDA receptors is blocked by nitroarginine. The exact mechanism whereby NO enhances neurotransmitter release is unclear, but may involve phosphorylation of synaptic vesicle proteins through activation of guanylyl cyclase.

NO has been implicated in hippocampal long-term potentiation (LTP), and perhaps NO's enhancement of neurotransmitter release facilitates the neurotransmission that accounts for LTP. For instance, injection of nitroarginine into the postsynaptic CA1 pyramidal cells of the hippocampus inhibits presynaptic LTP (Schuman and Madison, 1991), suggesting that NO might act as a retrograde messenger for LTP (Bohme et al., 1991; O'Dell et al., 1991; Haley et al., 1992). Despite the electrophysiologic evidence for NO in hippocampal LTP, neuronal NOS was not found within the postsynaptic CAl pyramidal cells (Bredt and Snyder, 1992). NADPH-diaphorase staining has yielded inconsistent staining of CA1 pyramidal neurons (Bredt et al., 1991a; Schmidt et al., 1992a; Vincent and Kimura, 1992). Very low levels of CAl pyramidal cell staining were observed with a neuronal NOS antibody under special fixation procedures using much higher concentrations of the NOS antibody than are required for staining of other NOS ncurons (Schweizer ct al., 1993). Recently, endothelial NOS was shown to be highly concentrated in CAl pyramidal cells and dendrites, and under glutaraldehyde fixation CAl pyramidal cells stain for NADPH dia- phorase; thus, endothelial NOS may generate the NO that has been postulated as a retrograde messenger in LTP (Dinerman et al., 1994).

A specific neurotransmitter function of NO has been demonstrated in the autonomic PNS. Throughout the gastrointestinal tract, NOS neurons are present in the myenteric plexus (Bredt et al., 1990; T. M. Dawson et al., 1991). Depolarization of myenteric plexus neurons relaxes smooth muscle associated with peristalsis. Blockade of this process by NOS inhibitors indicates that NO is the transmitter for NANC relaxation of the gut (Snipes et al., 1987; Bult et al., 1990; Desai et al., 1991; Tottrup et al., 1991).

NOS neurons are also prominent in penile tissue, specifically in the pelvic plexus and its axonal processes that form the cavernous nerve as well as the nerve plexus in the adventitia of the deep cavernosal arteries and the sinusoids in the periphery of the corpora cavernosa (Burnett et al., 1992). Intravenous injection of NOS inhibitors blocks the penile erection that is elicited upon electric stimulation of the cavernous nerve (Burnett et al., 1992). Nerve-stimulated relaxation of isolated cavernosa strips is also blocked by NOS inhibitors (Rajfer et al., 1992). These findings establish NO as the NANC transmitter mediating penile erection.

In the cerebral cortical and retinal blood vessels, besides localizations in the endothelium, NOS occurs in autonomic nerves in the outer, adventitial layers. These neurons derive from cells primarily in the sphenopalatine ganglia at the base of the skull (Nozaki et al., 1993; Yamamoto et al., 1993), which also contain the neuropeptide, vasoactive intestinal polypeptide (Nozaki et al., 1993). NO mediates vasodilation in the cerebral arteries through an NANC mechanism (Faraci, 1992; Prado et al., 1992; Toda et al., 1993). Cerebral blood flow is regulated by NO released both from endothelial cells as well as from the autonomic nerves within the adventitia. NO may also regulate cerebral blood flow through activity-dependent activation of NOS neurons influencing the small cerebral arterioles (Iadecola, 1993).

NOS occurs in discrete ganglion cells and fibers in the adrenal medulla (Bredt et al., 1990; T. M. Dawson et al., 1991), where it may regulate blood flow through a NANC mechanism (Breslow et al., 1992). NOS is also prominent within the posterior pituitary gland in fibers and terminals, where the function of NO has not yet been established.

In the spinal cord NOS is localized in the substantia gelatinosa and the intermediolateral cell column and neurons around the central canal. In these areas, NOS may influence functions of the sympathetic and parasympathetic autonomic nervous system (Meller and Gebhart, 1993). Indeed, NO has been implicated as a mediator of pain, since inhibitors of NOS attenuate thermal hyperalgesia (Meller and Gebhart, 1993). NO may also be involved in morphine tolerance, since coadministration of nitroarginine with morphine markedly retards the development of tolerance (Kolesnikov et al., 1993). Nitroarginine does not prevent tolerance to analgesia mediated by the $\kappa$-selective opiate agonists indicating that $\mathrm{NO}$ has a selective action in $\mu$-opiate tolerance.

Homologous genetic recombination techniques have recently been used to disrupt the murine gene encoding neuronal NOS and produce homozygous neuronal NOS "knockout" mice (Huang et al., 1993). The animals are normal in most respects despite their lack of NOS catalytic activity in the brain and loss of NOS immunostaining in central and peripheral neurons. Gross and microscopic examination fails to reveal morphologic ab- 
normalities in the brain and most peripheral tissue. However, the stomachs of null mice are grossly distended, and histologic examination shows hypertrophy of the circular muscle layer, especially in the pyloric region, consistent with chronic muscle contraction. The pathology resembles hypertrophic pyloric stenosis, in which the lack of NO may play a role since a recent study shows an absence of NADPH-diaphorase staining in the myenteric neurons of human male infants with pyloric stenosis (Vanderwinden et al., 1992). NADPH-diaphorase staining is normal outside the pyloric region in these patients, so that a generalized deficiency in neuronal NOS is probably not the cause of this disorder.

Although NO increases cGMP levels, the exact function of cGMP in the brain remains obscure, though it is known to activate cGMP-dependent serine/threonine protein kinase, cGMP-dependent cation channels (Light et al., 1989; Fesenko et al., 1991), and cGMP-dependent phosphodiesterases (Beavo and Reifsnyder, 1990). NO activation of the cGMP pathway in rat dorsal root ganglion cells desensitizes bradykinin inward cation currents (McGehee et al., 1992), indicating that NO may be involved in desensitization pathways. cAMP signaling may also be regulated by cGMP-modulated phosphodiesterases that hydrolyze cAMP. An interaction between cAMP and CGMP mediates NO activation of immediate early gene expression in PC-12 cells (Peunova and Enikolopov, 1993).

NO binds iron in the heme of guanylyl cyclase, altering the enzyme's conformation to activate it. In addition, NO can bind to non-heme iron in numerous enzymes such as NADH: succinate oxidoreductase, NADH-ubiquinone oxidoreductase, and cis-aconitase, all iron-sulfur-containing enzymes (Hibbs et al., 1990; Nathan, 1992). NO can also bind to the iron in ferritin, an iron storage protein, liberating the iron that could cause lipid peroxidation (Reif and Simmons, 1990). NO may inhibit DNA synthesis through binding the non-heme iron of ribonucleotide reductase (Lepoivre et al., 1990; Kwon et al., 1991). The ability of NO to bind iron could influence iron metabolism. Iron metabolism is regulated posttranscriptionally by specific mRNAprotein interactions. Iron-responsive elements (IRE) occur in mRNA encoding the erythroid form of 5-aminolevulinate synthase, ferritin, and the transferrin receptor (Klausner and Rouault, 1993; Munro, 1993). A soluble protein, IRE-binding protein (IRE-BP), binds to IRE, regulating expression of proteins whose mRNA contain IRE motifs. NO augments the IRE-binding activity of IRE-BP, influencing iron metabolism at the posttranscriptional level (Drapier et al., 1993; Weiss et al., 1993). NO produced by NMDA receptor activation of cerebellar slices also augments the mRNA binding activity of IRE-BP (S. E. Jaffrey, N. Cohen, T. A. Rouault, R. D. Klausner, and S. H. Snyder, unpublished observations).

$\mathrm{NO}$ influences the activity of cyclooxygenase, which contains heme (Salvemini et al., 1993). Cyclooxygenase is the rate-limiting enzyme in the biosynthesis of prostaglandins, thromboxane $A_{2}$ and prostacyclins. NO increases prostaglandin production by activation of cyclooxygenase (Salvemini et al., 1993). In macrophages, the NO-mediated increase in the production of proinflammatory prostaglandins through activation of cyclooxygenase may result in an exacerbated inflammatory response. In the hypothalamus, NO may mediate norepinephrine-induced prostaglandin $\mathrm{E}_{2}$ release by activating cyclooxygenase (Rettori et al., 1992). Corticotropin-releasing hormone release from the hypothalamus (Costa et al., 1993; Karanth et al., 1993) stimulated by $\mathrm{IL}_{2}$ or carbachol occurs through increases in prostaglandin
$E_{2}$ levels by virtue of NOS activation of cyclooxygenase (Karanth et al., 1993).

NO can stimulate the S-nitrosylation of many proteins (Stamler et al., 1992a,b). Nitrosylation of the NMDA receptor by NO inactivates it (Lipton et al., 1993) and may physiologically modulate glutamatergic transmission (Manzoni and Bockaert, 1993). NO stimulates the apparent autoADP-ribosylation of glyceraldehyde-3-phosphate dehydrogenase (Dimmeler et al., 1992; Kots et al., 1992; Zhang and Snyder, 1992). This reaction involves a cysteine at the active site of the enzyme, inhibiting catalytic activity and potentially depressing glycolysis. The apparent ADPribosylation may reflect a direct binding of NAD to the cysteine by S-nitrosylation (McDonald and Moss, 1993).

\section{NO as a neurotoxin}

Although NO mediates normal synaptic transmission, it may be neurotoxic under conditions of excessive formation of NO. Glutamate released in excess acting primarily through NMDA receptors mediates neurotoxicity in focal ischemia since the neurotoxicity is blocked by NMDA antagonists (Choi, 1988; Meldrum and Garthwaite, 1990). Glutamate neurotoxicity may also contribute to neurodegeneration in Alzheimer's and Huntington's diseases. Presumably activation of NMDA receptors and the subsequent increase in intracellular $\mathrm{Ca}^{2+}$ levels initiate most forms of glutamate neurotoxicity (Meldrum and Garthwaite, 1990). Glutamate neurotoxicity is attributable at least, in part, to NOS activation evoked by the increased intracellular $\mathrm{Ca}^{2+}$ concentration. In primary cultures of cerebral cortical neurons, in which a short $(5 \mathrm{~min})$ exposure to NMDA $(500 \mu \mathrm{M})$ normally elicits cell death 24 hr later, inhibitors of NOS, including arginine analogs, calmodulin antagonists, and flavoprotein inhibitors, and reduced hemoglobin, which scavenges NO, markedly attenuate neurotoxicity (V. L. Dawson et al., 1991, 1993a). Glutamate neurotoxicity is also diminished by culture in L- arginine-free media (V. L. Dawson et al., 1991, 1993a). Blockade of toxicity by NOS inhibitors is also observed in cultures of caudate-putamen and hippocampus (V. L. Dawson et al., 1993a). Superoxide dismutase (SOD), which scavenges the superoxide anion, attenuates glutamate neurotoxicity, implicating the superoxide anion in components of this process (V. L. Dawson et al., 1993a). NO and the superoxide anion may interact to form peroxynitrite, which is the ultimate toxic molecule (Beckman et al., 1990; Bcckman, 1991; Radi et al., 199 1a,b). NO has been implicated in glutamate neurotoxicity in a variety of tissues including striatal slices (Kollegger et al., 1993), hippocampal slices (Izumi et al., 1992; Moncada et al., 1992; Wallis et al., 1992), and culture conditions (Corasaniti et al., 1992; Lustig et al., 1992; Tamura et al., 1992; Cazevieille et al., 1993). Prolonged application of NOS inhibitors after the initial exposure to excitatory amino acids leads to enhanced neuroprotection (Reif, 1993; Vige et al., 1993). Despite the above-cited evidence for a role of $\mathrm{NO}$ in glutamate neurotoxicity other investigators failed to confirm that $\mathrm{NO}$ is a necessary link in this phenomenon (Demerle-Pallardy et al., 1991; Pauwels and Leysen, 1992; Regan et al., 1993) or even provided evidence that NO may protect neurons form glutamate toxicity (Lei et al., 1992). These discrepancies have been resolved by the finding that NO may possess either neurodestructive and neuroprotective properties, depending upon its oxidation-reduction status, with $\mathrm{NO}$ being neurodestructive and $\mathrm{NO}^{+}$being neuroprotective (Lipton et al., 1993).

If NO is responsible for neuronal damage in vascular stroke, 
inhibitors of NOS should be neuroprotective. Low doses of nitroarginine reduce infarct volume following middle cerebral artery occlusion in rats (Buisson et al., 1992; Nagafuji et al., 1992; Trifiletti, 1992; Buisson et al., 1993), cats (Nishikawa et al., 1993), and mice (Nowicki et al., 1991). High doses of NOS inhibitors exacerbate the damage following occlusion of the middie cerebral artery, presumably by decreasing cerebral blood flow (Dawson et al., 1992; Yamamoto et al., 1992).

NOS neurons are peculiar, in that they are resistant to NMDA toxicity and exquisitely sensitive to quisqualate and kainate neurotoxicity (Koh and Choi, 1988). Low-dose quisqualate pretreatment of cortical cultures selectively kills NOS neurons, while non-NOS neurons remain viable (V. L. Dawson ct al., 1993a). Quisqualate-pretreated cortical cultures are resistant to NMDA toxicity (V. I. Dawson et al., 1993a). Thus, NOS neurons release NO to kill non-NOS neurons. The peculiar resistance of NOS neurons to NMDA toxicity is puzzling (V. L. Dawson et al., 1993a). Perhaps the diaphorase activity of NOS protects the cell against $\mathrm{NO}$, as induction of a related diaphorase enzyme renders a non-NQS neuronal cell line resistant to glutamate toxicity (Murphy et al., 1991). NOS neurons within the striatum are enriched in manganese SOD (Inagaki et al., 1991), and SOD in these neurons may prevent the local formation of toxic peroxynitrite rendering NOS neurons resistant to the toxic actions of NO. Another possibility involves a potential intracellular translocation of neuronal NOS that has been demonstrated for endothelial NOS (Michel et al., 1993). Phosphorylation of endothelial NOS translocates it from membrane to cytosol. Since phosphorylated NOS is catalytically inactive, NO will not be generated within the cytoplasm. Instead, catalytically active, nonphosphorylated NOS is restricted to the plasma membrane, where it presumably generates NO that is released into the extracellular space. Neuronal NOS is present in both the particulate and soluble fractions (Hiki et al., 1993). Thus, it is conceivable that within neurons the active form of NOS occurs at the plasma membrane, where it releases NO to the outside, and no NO would be produced in the interior of NOS cells, rendering them resistant to NO damage.

Other types of neurotoxicity can be mediated by NO. The pathogenesis of AIDS dementia has remained elusive, as HIV-1 infection has been detected in macrophages and microglia but not in neurons (Koenig et al., 1986; Giulian et al., 1990; Watkins et al., 1990). Neuronal cell death might involve the HIV-1 coat protein, gpl20, which is shed by the virus, since picomolar concentrations of gp 120 kill neurons in primary cortical cell cultures (Brenneman et al., 1988; Dreyer et al., 1990). Neuronal cell death elicited by gp 120 is absolutely dependent upon the presence of glutamate acting through NMDA receptors (Lipton et al., 1991; V. L. Dawson et al., 1993b). This neurotoxicity is mediated, at least in part, by NO since inhibitors of NOS and culture in arginine-free medium block gp120 neurotoxicity (V. L. Dawson et al., 1993b). How gp120 elicits the formation of NO is unclear, but gp120 neurotoxicity requires the presence of macrophages and/or astrocytes (Lipton, 1992), and these cells produce cytokines and arachidonic acid metabolites that can potentiate NMDA receptor currents. Conceivably, gp 120 elicits release of arachidonic acid metabolites and/or cytokines from macrophages and glia, which synergize with glutamate to activate NMDA receptors that in turn enhance the formation of NO, which is toxic to neurons (Fig. 3).

NOS can be inhibited indirectly, which thus provides alternative strategies for protection against NO-mediated cell death.

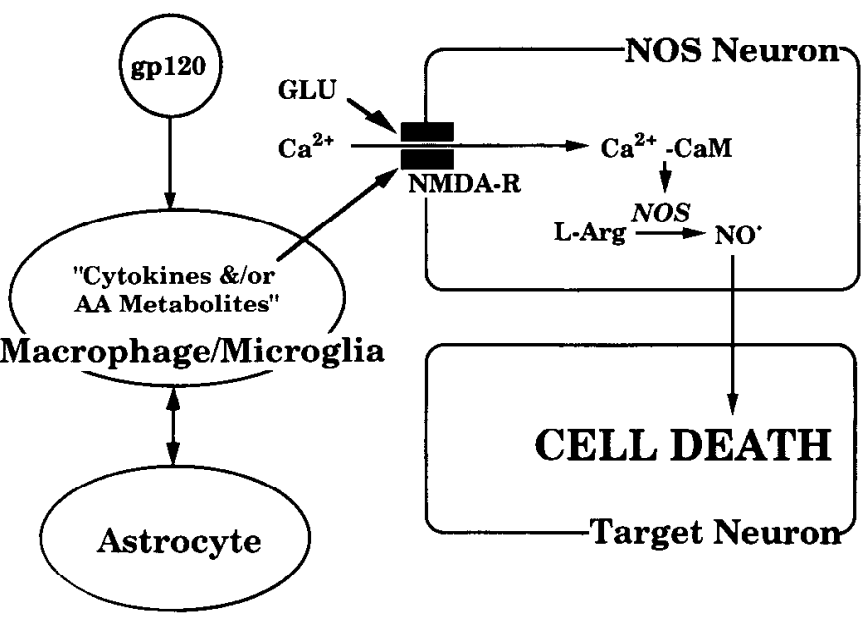

Figure 3. gp 120-induced neurotoxicity. gp 120, the HIV-1 coat protein, may elicit neurotoxicity by interacting with macrophage/microglia and astrocytes to release cytokines and/or arachidonic acid metabolites. Glutamate then interacts with the cytokines and/or arachidonic acid metabolites to activate NMDA receptors $(N M D A-R)$, which increases intracellular $\mathrm{Ca}^{2+}$ levels. Reaction of $\mathrm{Ca}^{2+}$ with calmodulin $(\mathrm{CaM})$ activates NOS and the NO released in the medium kills adjacent neurons. Figure is from V. L. Dawson et al. (1993b).

Gangliosides are neuroprotective in spinal cord injury in human patients as well as in animal models of other types of neuronal damage (Manev et al., 1990; Geisler et al., 1992; Mahadik, 1992; Skaper and Leon, 1992). Gangliosides prevent glutamate neurotoxicity in neuronal cultures because they inhibit NOS activity (T. M. Dawson et al., 1994). The protective potency of gangliosides closely parallels their affinities for calmodulin (Higashi and Yamagata, 1992; Higashi et al., 1992) and their potency for inhibiting NOS (T. M. Dawson et al., 1994).

Phosphorylation of NOS and the attendant reduction of its catalytic activity provides another potential approach to protection. The immunosuppressants FK506 and cyclosporin-A bind to small soluble receptor proteins designated FK506-binding proteins (FKBP) and cyclophilins, respectively. The drug receptor complex in turn binds to the $\mathrm{Ca}^{2+}$-activated phosphatase calcineurin and inhibits its activity (Fruman et al., 1992; Liu et al., 1991, 1992; Swanson et al., 1992). The inhibition of calcineurin accounts for FK506 and cyclosporin-A's immunosuppressant actions on $T$ cells and explains their effects in the CNS as these drugs lead to an accumulation of phosphorylated substrates of calcineurin (Steiner et al., 1992). NOS is a calcineurin substrate, and the abundance of phosphorylated catalytically inactive NOS is enhanced by FK 506 and cyclosporin-A (T. M. Dawson et al., 1993). Accordingly, since they favor the accumulation of catalytically inactive NOS, FK506 and cyclosporin-A provide protection against glutamate toxicity (Fig. 4). The neuroprotective cffects of the immunosuppressants may have clinical relevance, as cyclosporin-A reduces infarct volume following middle cerebral artery infarction in rats (Shiga et al., 1992).

The toxic effects mediated by NO probably evolve from its interaction with the superoxide anion to form peroxynitrite (Beckman et al., 1990; Beckman, 1991; Radi et al., 1991a,b). Recent studies provide evidence that DNA damage is the key to NO neurotoxicity (J. Zhang et al., 1994). DNA damage by NO, as with other free radicals, occurs through nucleotide base deamination (Wink et al., 1991). Repair of base deamination 


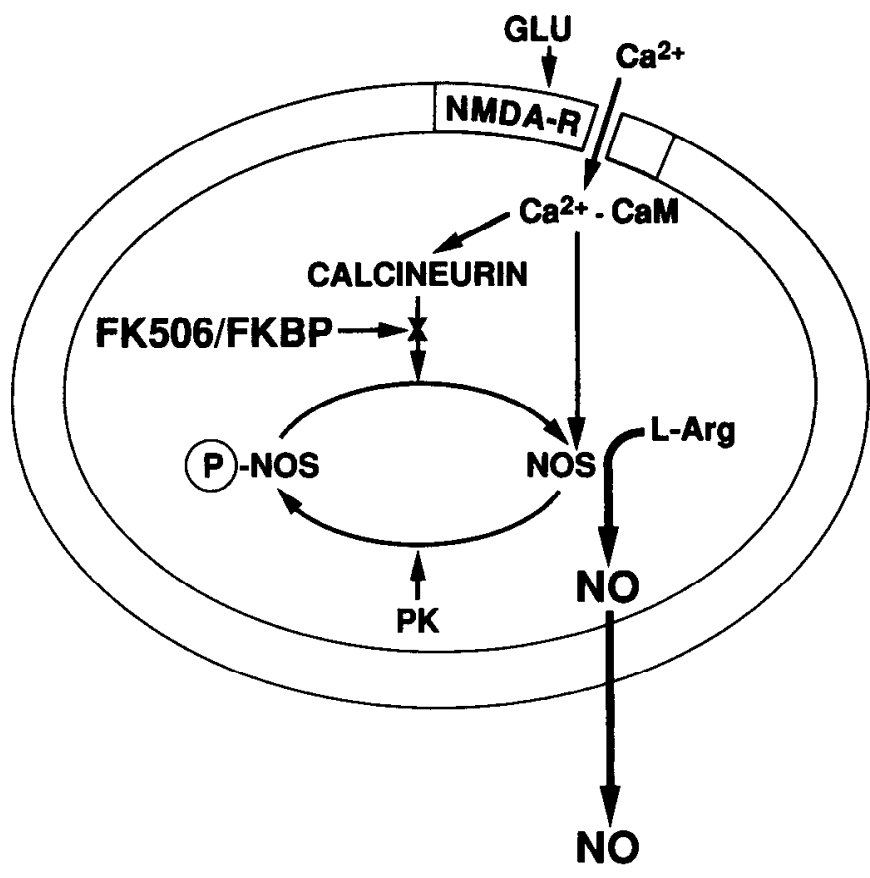

Figure 4. Regulation of the phosphorylation state and catalytic activity of NOS. NMDA receptor (NMDA-R) activation increases intracellular $\mathrm{Ca}^{2+}$ levels, which activates NOS and calcineurin via calmodulin $(\mathrm{CaM})$. NOS catalytic activity is inhibited by protein kinase $(P K)$-mediated phosphorylation by cAMP and cGMP-dependent protein kinases, protein kinase $\mathrm{C}$ and $\mathrm{Ca}^{2+} /$ calmodulin-dependent protein kinase. $\mathrm{Ca}^{2+}$ entry activates calcineurin, which dephosphorylates and reactivates NOS. FK506, complexed to FKBP, binds to calcineurin and inhibits its phosphatase activity. This prevents the dephosphorylation of NOS, thus decreasing NOS catalytic activity. NO production is consequently lowered, and adjacent neurons survive. Figure is from T. M. Dawson et al. (1993).

leads to DNA fragmentation, which stimulates the activity of the nuclear enzyme poly (ADP ribose) synthetase (PARS). Utilizing NAD as a substrate, PARS catalyzes the attachment of 50-100 ADP-ribose units per molecule of nuclear proteins such as histones and, most prominently, to PARS itself (de Murcia et al., 1991). NO stimulates the polyADP-ribosylation of PARS in brain homogenates by damaging DNA (J. Zhang et al., 1994). In cortical cell cultures, glutamate neurotoxicity is blocked by a series of PARS inhibitors, whose capacity for neuroprotection increase with their potencies for PARS inhibition (J. Zhang et al., 1994). These observations indicate the following scenario for NO neurotoxicity (Fig. 5). DNA damage produced by NO causes a massive activation of PARS, which severely depletes the cell of NAD and ATP. For each mole of ADP-ribose transferred, $1 \mathrm{~mol}$ of NAD and, through the regeneration of NAD, the free energy equivalent of $4 \mathrm{~mol}$ of ATP are consumed. Since NO poisons the mitochondrial electron transport chain as well, PARS activation can lead to a rapid depletion in energy stores. With lesser degrees of DNA damage, PARS activation is thought to facilitate DNA repair (Gaal et al., 1987).

\section{Carbon monoxide as a neural messenger}

NO may not be the only gaseous, labile small molecule neurotransmitter, in that $\mathrm{CO}$ has recently turned up as another neurotransmitter candidate. $\mathrm{CO}$ is produced by heme oxygenase which cleaves the heme ring into $\mathrm{CO}$ and biliverdin, which is rapidly reduced to bilirubin. There are at least two isoforms of

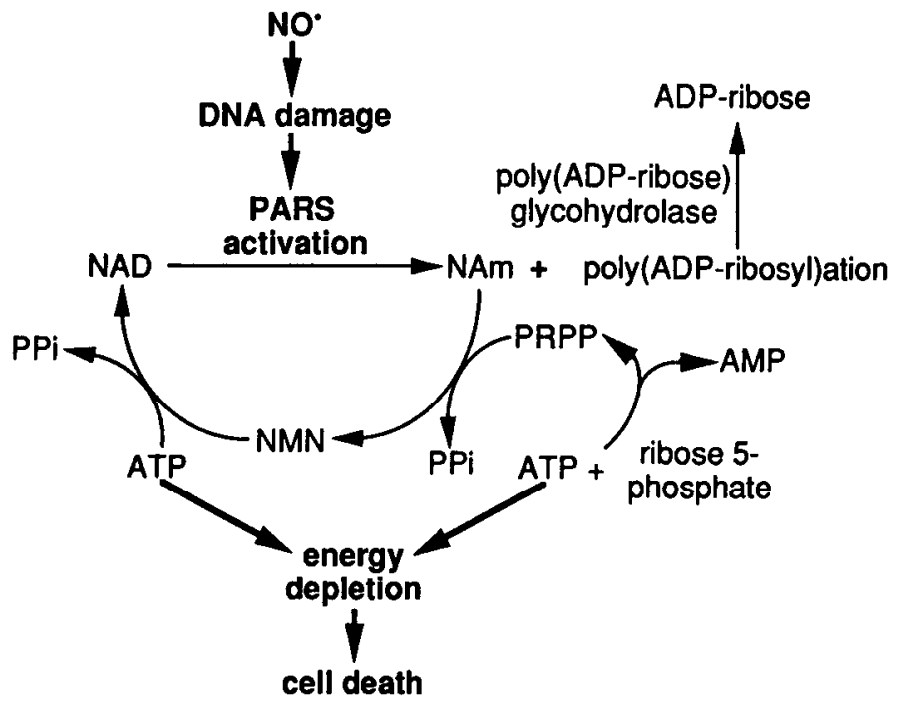

Figure 5. NO-mediated neurotoxicity. DNA damaged by NO activates poly(ADP-ribose) synthetase ( $P A R S$ ), which coverts nicotinamide adenine dinucleotide $(N A D)$ to nicotinamide $(N A m)$. Poly(ADP-ribose) is rapidly degraded to ADP-ribose by poly(ADP-ribose) glycohydrolase. NAD is resynthesized from NAm via nicotinamide mononucleotide $(N M N)$, a reaction that consumes phosphoribosyl pyrophosphate (PRPP) and ATP. This futile cycle continues during the prolonged PARS activation, depleting the cell's energy and ultimately leading to its death. From J. Zhang et al. (1994).

heme oxygenase (HO). HOl is inducible and is responsible for the destruction of heme in senescent red blood cells (Cruse and Maines, 1988; Sun et al., 1990). Expression of HOl protein is induced in response to accumulation of heme, as well as by oxidative stressors. The other isoform, $\mathrm{HO} 2$, is constitutive. $\mathrm{HO} 1$ is concentrated in peripheral tissues, such as the spleen and liver, whereas $\mathrm{HO} 2$ occurs in high densities in the brain (Sun et al., 1990; Verma et al., 1993). IIO resembles NOS in that the electrons for $\mathrm{CO}$ synthesis are donated by CPR. CO, like NO, binds to the iron in heme in guanylate cyclase to activate cGMP (Brüne and Ullrich, 1987; Gräser et al., 1990; Furchgott and Jothianandan, 1991; Marks et al., 1991). CO's affinity for heme accounts for its lethality, in that it prevents hemoglobin from delivering oxygen to the tissues. HO was generally thought to serve primarily for heme catabolism. However, it was found that in cultures of olfactory neurons, $\mathrm{CO}$ is responsible for maintaining endogenous cGMP levels, since potent and selective inhibitors of $\mathrm{HO}$, but not NOS inhibitors, deplete cGMP levels (Verma et al., 1993). Moreover, a variety of odorants seemed to enhance the level of cGMP via a COdependent mechanism (Verma et al., 1993). Further evidence that $\mathrm{HO}$ may play a role in neurotransmission is that $\mathrm{HO}$ displays selective localizations in the brain. For instance, high concentrations of $\mathrm{HO} 2$ are present in hippocampal pyramidal and granule cells. In the cerebellum, high concentrations are present in the granule and Purkinje cell layers. $\mathrm{HO} 2$ is also found in the piriform cortex, tenia tecta, olfactory tubercle, and islands of Callejae (Verma et al., 1993). Highest concentrations in the brain occur in the neurons of the olfactory epithelium and in the neuronal and granule cell layers of the olfactory bulb (Verma et al., 1993). Immunohistochemical studies of HO2 provide somewhat similar localizations (Ewing and Maines, 1992; J. L. Dinerman and S. H. Snyder, unpublished observations).

Although $\mathrm{CO}$ has only been recently identified in the brain, 
it has been implicated in various physiologic functions. With $\mathrm{HO} 2$ being concentrated in hippocampal pyramidal cells, $\mathrm{CO}$ might be a candidate retrograde messenger for LTP since the HO inhibitor zinc protoporphyrin IX (ZnPP-9) blocks the induction of LTP in hippocampal slices (Stevens and Wang, 1993; Zhuo et al., 1993). In addition, long-lasting increases in the amplitude of evoked potentials are observed when $\mathrm{CO}$ is applied at the same time as a weak tetanic stimulation (Zhuo et al., 1993).

NO primarily mediates glutamate action at NMDA receptors and $\mathrm{CO}$ may be primarily responsible for mediating glutamate action at metabotropic receptors. Metabotropic receptor activation in the nucleus tractus solitarius of the brain stem regulates the conductance of a specific channel via a cGMP-dependent mechanism. ZnPP-9 and other antagonists block effects of receptor stimulation in proportion to their potencies as inhibitors of $\mathrm{HO}$, while NOS inhibitors do not reduce the agonist induced increase in channel conductance (Glaum and Miller, 1993).

The chemosensors of the carotid body may also be subject to regulation by $\mathrm{CO}$. They are activated by molecular oxygen and inhibited by $\mathrm{CO}$ (Gonzalez et al., 1992). The carotid body possesses high concentrations of $\mathrm{HO} 2$ protein, as determined immunohistochemically (J. L. Dinerman, N. R. Prabhakar, and S. H. Snyder, unpublished observations), and ZnPP-9 markedly enhances chemosensory discharges of the carotid body (Prabhakar et al., 1993).

\section{Summary}

In a remarkably brief period of time, $\mathrm{NO}$ and $\mathrm{CO}$ have been recognized as putative neurotransmitters. These two novel messenger molecules have greatly expanded the criteria for candidacy of a chemical for the status of neurotransmitter and our notions about how synaptic transmission takes place. The involvement of $\mathrm{NO}$ and $\mathrm{CO}$ in several important aspects of ncuronal function suggests that agents affecting the synthesis, transactions, and disposition of these gases are bound to have clinical relevance.

\section{References}

Arnold WP, Mittal CK, Katsuki S, Murad F (1977) Nitric oxide activates guanylate cyclase and increases guanosine $3^{\prime}: 5^{\prime}$-cyclic monophosphate levels in various tissue preparations. Proc Natl Acad Sci USA 74:3203-3207.

Assreuy J, Cunha FQ, Liew FY, Moncada S (1993) Feedback inhibition of nitric oxide synthase activity by nitric oxide. Br J Pharmacol 108:833-837.

Beavo JA, Reifsnyder DH (1990) Primary sequence of cyclic nucleotide phosphodiesterase isozymes and the design of selective inhibitors. Trends Pharmacol Sci 11:150-155.

Beckman JS (1991) The doubled-edged role of nitric oxide in brain function and superoxide-mediated injury. J Dev Physiol 15:53-59.

Beckman JS, Beckman TW, Chen J, Marshall PA, Freeman BA (1990) Apparent hydroxyl radical production by peroxynitrite: implications for endothelial injury from nitric oxide and superoxide. Proc Natl Acad Sci USA 87:1620-1624.

Boeckxstaens GE, Pelckmans PA, Ruytjens IF, Bult H, DeMan JG, Herman AG, VanMaercke YM (1991) Bioassay of nitric oxide released upon stimulation of non-adrenergic non-cholinergic nerves in the canine ileocolonic junction. $\mathrm{Br} \mathrm{J}$ Pharmacol 103:1085.

Bohme GA, Bon C, Stutzmann J-M, Doble A, Blanchard J-C (1991) Possible involvement of nitric oxide in long-term potentiation. Eur J Pharmacol 199:379-381.

Bredt DS, Snyder SH (1989) Nitric oxide mediates glutamate-linked enhancement of cGMP levels in the cerebellum. Proc Natl Acad Sci USA 86:9030-9033.

Bredt DS, Snyder SH (1990) Isolation of nitric oxide synthetase, a calmodulin-requiring enzyme. Proc Natl Acad Sci USA 87:682-685.
Bredt DS, Snyder SH (1992) Nitric oxide, a novel neuronal messenger. Neuron 8:3-11.

Bredt DS, Hwang PM, Snyder SH (1990) Localization of nitric oxide synthase indicating a neural role for nitric oxide. Nature 347:768770.

Bredt DS, Glatt CE, Hwang PM, Fotuhi M, Dawson TM, Snyder SH (1991a) Nitric oxide synthase protein and mRNA are discretely localized in neuronal populations of the mammalian CNS together with NADPH diaphorase. Neuron 7:615-624.

Bredt DS, Hwang PH, Glatt C, Iowenstein C, Reed RR, Snyder SH (1991b) Cloned and expressed nitric oxide synthase structurally resembles cytochrome $P-450$ reductase. Nature 351:714-718.

Bredt DS, Ferris CD, Snyder SH (1992) Nitric oxide synthase regulatory sites. J Biol Chem 267:10976-10981.

Brenneman DE, Westbrook GL, Fitzgerald SP, Ennist DL, Elkins KL, Ruff MR, Pert CB (1988) Neuronal cell killing by the envelope protein of HIV and its prevention by vasoactive intestinal peptide. Nature 335:639-642.

Breslow MJ, Tobin JR, Bredt DS, Ferris CD, Snyder SH, Traystman RJ (1992) Role of nitric oxide in adrenal medullary vasodilation during catecholamine secretion. Eur J Pharmacol 87:682-685.

Brüne B, Lapetina EG (1991) Phosphorylation of nitric oxide synthase by protein kinase A. Biochem Biophys Res Commun 181:921-926.

Brüne B, Ullrich V (1987) Inhibition of platelet aggregation by carbon monoxide is mediated by activation of guanylate cyclase. Mol Pharmacol 32:497-504.

Buisson A, Plotkine M, Boulu RG (1992) The neuroprotective effect of a nitric oxide inhibitor in a rat model of focal cerebral ischemia. Br J Pharmacol 106:766-767.

Buisson A, Margaill I, Callebert J, Plotkine M, Boulu RG (1993) Mechanisms involved in the neuroprotective activity of a nitric oxide synthase inhibitor during focal ecrcbral ischemia. J Neurochem 61:690696.

Bult H, Boeckxstaens GE, Pelckmans PA, Jordaens FH, Van Maercke YM, Herman AG (1990) Nitric oxide as an inhibitory non-adrenergic non-cholinergic neurotransmitter. Nature 345:346-347.

Burnett AL, Lowenstein CJ, Bredt DS, Chang TSK, Snyder SH (1992) Nitric oxide: a physiologic mediator of penile erection. Science 257: 401-403.

Busconi L, Michel T (1993) Endothelial nitric oxide synthase. N-terminal myristoylation determines subcellular localization. J Biol Chem 268:8410-8413.

Cazevieille C, Muller A, Meynier F, Bonne C (1993) Superoxide and nitric oxide cooperation in hypoxia/reoxygenation-induced neuron injury. Free Radical Biol Med 14:389-395.

Charles IG, Palmer MJ, Hickery MS, Bayliss MT, Chubb AP, Hall VS, Moss DW, Moncada S (1993) Cloning, characterization and expression of a cDNA encoding an inducible NO synthase from the human chondrocyte. Proc Natl Acad Sci USA 90:11419-11423.

Cho HJ, Xie Q-W, Calaycay J, Mumford RA, Swiderek KM, Lee TD, Nathan C (1992) Calmodulin as a tightly bound subunit of calcium-, calmodulin-independent nitric oxide synthase. J Exp Med 176:599604

Choi DW (1988) Glutamate neurotoxicity and diseases of the nervous system. Neuron 1:623-634.

Corasaniti M, Tartaglia RL, Melino G, Nistico G, Finazzi-Agro A (1992) Evidence that CHP100 neuroblastoma cell death induced by $\mathrm{N}$-methyl-D-aspartate involves L-arginine-nitric oxide pathway activation. Neurosci Lett 147:221-223.

Costa A, Trainer P, Besser M, Grossman A (1993) Nitric oxide modulates the release of corticotropin-releasing hormone from the rat hypothalamus in vitro. Brain Res 605:187-192.

Cruse I, Maines MD (1988) Evidence suggesting that the two forms of heme oxygenase are products of different genes. J Biol Chem 263: 3348-3353.

Dawson DA, Kusumoto K, Graham DI, McCulloch J, Macrae IM (1992) Inhibition of nitric oxide synthesis does not reduce infarct volume in a rat model of focal cerebral ischaemia. Neurosci Lett 142: 151-154.

Dawson TM, Bredt DS, Fotuhi M, Hwang PM, Snyder SH (1991) Nitric oxide synthase and neuronal NADPH diaphorase are identical in brain and peripheral tissues. Proc Natl Acad Sci USA 88:77977801.

Dawson TM, Steiner JP, Dawson VL, Dinerman JL, Uhl GR, Snyder SH (1993) Immunosuppressant, FK506, enhances phosphorylation 
of nitric oxide synthase and protects against glutamate neurotoxicity. Proc Natl Acad Sci USA 90:9808-9812.

Dawson TM, Hung K, Dawson VL, Steiner JP, Snyder SH (1994) Neuroprotective effects of gangliosides may involve inhibition of nitric oxide synthase. Ann Neurol, in press.

Dawson VL, Dawson TM, London ED, Bredt DS, Snyder SH (1991) Nitric oxide mediates glutamate neurotoxicity in primary cortical culture. Proc Natl Acad Sci USA 88:6368-6371.

Dawson VL, Dawson TM, Bartley DA, Uhl GR, Snyder SH (1993a) Mechanisms of nitric oxide mediated neurotoxicity in primary brain cultures. J Neurosci 13:2651-2661.

Dawson VL, Dawson TM, Uhl GR, Snyder SH (1993b) Human immunodeficiency virus type 1 coat protein neurotoxicity mediated by nitric oxide in primary cortical cultures. Proc Natl Acad Sci USA 90: 3256-3259.

Demerle-Pallardy C, Lonchampt MO, Chabrier PE, Braquet P (1991) Absence of implication of L-arginine/nitric oxide pathway on neuronal cell injury induced by L-glutamate or hypoxia. Biochem Biophys Res Commun 181:456-464.

de Murcia G, Menissier-de Murcia J, Schreiber V (1991) Poly(ADPribose) polymerase: molecular biological aspects. Bioessays 13:455462.

Desai KM, Sessa WC, Vane JR (1991) Involvement of nitric oxide in the reflex relaxation of the stomach to accommodate food or fluid. Nature 351:477-479.

Dickie BGM, Lewis MJ, Davies JA (1992) NMDA-induced release of nitric oxide potentiates aspartate overflow from cerebellar slices. Neurosci Lett 138:145-148.

Dimmeler S, Lottspeich F, Brune B (1992) Nitric oxide causes ADPribosylation and inhibition of glyccraldchyde-3-phosphatc dehydrogenase. J Biol Chem 267:16771-16774.

Dinerman JL, Dawson TM, Schell MJ, Snowman A, Snyder SH (1994) Endothelial nitric oxide synthase localized to hippocampal pyramidal cells: implications for synaptic plasticity. Proc Natl Acad Sci USA, in press.

Douglas TH, Patterson SI, Smith DS, Skene JH (1993) Neuronal growth cone collapse and inhibition of protein fatty acylation by nitric oxide. Nature 366:562-565.

Drapier JC, Hirling H, Weitzerbin J, Kaldy P, Kuhn L (1993) Biosynthesis of nitric oxide activates iron regulatory factor in macrophages. EMBO J 12:3643-3649.

Dreyer EB, Kaiser PK, Offermann JT, Lipton SA (1990) HIV-1 coat protein neurotoxicity prevented by calcium channel antagonists. Scicnce 248:364-367.

Evans T, Carpenter A, Cohen J (1992) Purification of a distinctive form of endotoxin-induced nitric oxide synthase from rat liver. Proc Natl Acad Sci USA 89:5361-5365.

Ewing JF, Maines MD (1992) In situ hybridization and immunohistochemical localization of heme oxygenase- 2 mRNA and protein in normal rat brain: differential distribution of isozyme 1 and 2 cell. Mol Cell Neurosci 3:559-570.

Faraci FM (1992) Regulation of the cerebral circulation by endothelium. Pharmacol Ther 56:1-22.

Ferrante RJ, Kowall NW, Beal MF, Richardson EP Jr, Bird ED, Martin JB (1985) Selective sparing of a class of striatal neurons in Huntington's disease. Science 230:561-563.

Fesenko EE, Kolesnikov SS, Lyubarsky AL (1991) Induction of cyclic GMP of cationic conductance in plasma membrane of retinal rod outer segment. Nature 313:310-313.

Fruman DA, Klee CB, Bierer BE, Burakoff SJ (1992) Calcineurin phosphatase activity in T lymphocytes is inhibited by FK506 and cyclosporin A. Proc Natl Acad Sci USA 89:3686-3690.

Furchgott RF, Jothianandan D (1991) Endothelium-dependent andindependent vasodilation involving cyclic GMP: relaxation induced by nitric oxide, carbon monoxide and light. Blood Vessels 28:52-61.

Furchgott RF, Zawadzki JV (1980) The obligatory role of endothelial cells in the relaxation of arterial smooth muscle by acetylcholine. Nature 288:373-376.

Gaal JC, Smith KR, Pearson CK (1987) Cellular euthanasia mediated by a nuclear enzyme: a central role for nuclear ADP-ribosylation in cellular metabolism. Trends Biol Sci 12:129-130.

Garthwaite J, Charles SL, Chess-Williams R (1988) Endothcliumderived relaxing factor release on activation of NMDA receptors suggests role as intercellular messenger in the brain. Nature 336:385388.
Garthwaite J, Garthwaite G, Palmer RMJ, Moncada S (1989) NMDA receptor activation induces nitric oxide synthesis from arginine in rat brain slices. Eur J Pharmacol 172:413-416.

Geisler FH, Dorsey FC, Coleman WP (1992) GM-1 ganglioside in human spinal cord injury. J Neurotrauma 9:S517-S530.

Geller DA, Lowenstein CJ, Shapiro RA, Nussler AK, Di Silvio M, Wang SC, Nakayama DK, Simmons RL, Snyder SH, Biliar TR (1993) Molecular cloning and expression of inducible nitric oxide synthase from human hepatocytes. Proc Natl Acad Sci USA 90:3491-3495.

Giovanelli J, Campos KL, Kaufman S (1991) Tetrahydrobiopterin, a cofactor for rat cerebellar nitric oxide synthase, does not function as a reactant in the oxygenation of arginine. Proc Natl Acad Sci USA 88:7091-7095

Giulian D, Vaca K, Noonan CA (1990) Secretion of neurotoxins by mononuclear phagocytes infected with HIV-1. Science 250:1593-1596.

Glaum SR, Miller RJ (1993) Zinc protoporphyrin-IX blocks the effects of metabotropic glutamate receptor activation in the rat nucleus tractus solitarii. Mol Pharmacol 43:965-969.

Gonzalez C, Almaraz L, Obeso A, Rigual R (1992) Oxygen and acid chemoreception in the carotid body chemoreceptors. Trends Neurosci 15:146-153.

Gräser T, Vedernikov YP, Li DS (1990) Study on the mechanism of carbon monoxide induced endothelium-independent relaxation in porcine coronary artery and vein. Biomed Biochim Acta 49:293-296.

Green LC, Ruiz-de-Luzuriaga K, Wagner DA, Rand W, Istfan N, Young VR, Tannenbaum SR (1981a) Nitrate biosynthesis in man. Proc Natl Acad Sci USA 78:7764-7768.

Green LC, Tannenbaum SR, Goldman P (1981b) Nitrate synthesis in the germfree and conventional rat. Science 212:56-58.

Halcy JE, Wilcox GL, Chapman PF (1992) The role of nitric oxide in hippocampal long-term potentiation. Neuron 8:211-216.

Hanbauer I, Wink D, Osawa Y, Edelman GM, Gally J (1992) Role of nitric oxide in NMDA-evoked release of $\left[{ }^{3} \mathrm{H}\right]$-dopamine from striatal slices. Neuroreport 3:409-412.

Hevel JM, Marletta MA (1992) Macrophage nitric oxide synthase: relationship between enzyme-bound tetrahydrobiopterin and synthase activity. Biochemistry 31:7160-7165.

Hevel JM, White KA, Marletta MA (1991) Purification of the inducible murine macrohage nitric oxide synthase. Identification as a flavoprotein. J Biol Chem 266:22789-22791.

Hibbs JB Jr, Taintor RR, Vavrin Z (1987) Macrophage cytotoxicity: role for $\mathrm{L}$-arginine deaminase and imino nitrogen oxidation to nitrite. Science 235:473-476.

Hibbs JB Jr, Taintor RR, Vavrin V, Granger DL, Drapier J-C, Amber IJ, Lancaster JR Jr (1990) Synthesis of nitric oxide from a guanidino nitrogen of L-arginine: a molecular mechanism that targets intracellular iron. In: Nitric oxide from L-arginine: a bioregulatory system (Moncada S, Higgs EA, eds), pp 189-223. Amsterdam: Elsevier.

Higashi H, Yamagata T (1992) Mechanism for ganglioside-mediated modulation of a calmodulin-dependent enzyme. Modulation of calmodulin-dependent cyclic nucleotide phosphodiesterase activity through binding of gangliosides to calmodulin and the enzyme. J Biol Chem 267:9839-9843.

Higashi H, Omori A, Yamagata T (1992) Calmodulin, a gangliosidebinding protein. Binding of gangliosides to calmodulin in the presence of calcium. J Biol Chem 267:9831-9838.

Hiki K, Hattori R, Kawai C, Yui Y (1993) Purification of insoluble nitric oxide synthasc from rat ccrebellum. J Biochem 111:556-558.

Hirsch DB, Steiner JP, Dawson TM, Mammen A, Hayek E, Snyder SH (1993) Neurotransmitter release regulated by nitric oxide in PC-12 cells and brain synaptosomes. Curr Biol 3:749-754.

Hope BT, Michael GJ, Knigge KM, Vincent SR (1991) Neuronal NADPH diaphorase is a nitric oxide synthase. Proc Natl Acad Sci USA 88:2811-2814.

Huang PL, Dawson TM, Bredt DS, Snyder SH, Fishman MC (1993) Targeted disruption of the neuronal nitric oxide synthase gene. Cell 75:1273-1286.

Hyman BT, Marzloff K, Wenniger JJ, Dawson TM, Bredt DS, Snyder SH (1992) Relative sparing of nitric oxide synthase-containing neurons in the hippocampal formation in Alzheimer's disease. Ann Neurol 32:818-820.

Iadccola C (1993) Regulation of the cerebral microcirculation during neural activity: is nitric oxide the missing link? Trends Neurosci 16: 206-214.

Ignarro LJ, Lippton H, Edwards JC, Baricos WH, Hyman AL, Kadowitz 
PJ, Gruetter CA (1981) Mechanism of vascular smooth muscle relaxation by organic nitrates, nitrites, nitroprusside and nitric oxide: evidence for the involvement of S-nitrosothiols as active intermediates. J Pharmacol Exp Ther 218:739-749.

Ignarro LJ, Buga GM, Wood KS, Byrns RE, Chaudhuri G (1987) Endothelium-derived relaxing factor produced and released from artery and vein is nitric oxide. Proc Natl Acad Sci USA 84:9265-9269.

Inagaki S, Suzuki K, Taniguchi N, Takagi H (1991) Localization of Mn-superoxide dismutase (Mn-SOD) in cholinergic and somatostatin-containing neurons in the rat neostriatum. Brain Res 549:174-177.

Izumi Y, Benz AM, Clifford DB, Zorumski CF (1992) Nitric oxide inhibitors attenuate $N$-methyl-D-aspartate excitotoxicity in rat hippocampal slices. Neurosci Lett 135:227-230.

Janssens SP, Shimouchi A, Quertermous T, Bloch DB, Bloch KD (1992a) Cloning and expression of a cDNA encoding human endothelium-derived relaxing factor/nitric oxide synthase. J Biol Chem 267:14519-14522.

Karanth S, Lyson K, McCann SM (1993) Role of nitric oxide in interleukin 2-induced corticotropin-releasing factor release from incubated hypothalami. Proc Natl Acad Sci USA 90:3383-3387.

Klatt P, Schmidt K, Mayer B (1992) Brain nitric oxide synthase is a haemoprotein. Biochem J 288:15-17.

Klatt P, Schmidt K, Uray G, Mayer B (1993) Multiple catalytic functions of brain nitric oxide synthase. Biochemical characterization, cofactor-requirement, and the role of $N$-omega-L-arginine as an intermediate. J Biol Chem 268:14781-14787.

Klausner RD, Rouault TA (1993) A double life: cytosolic aconitase as a regulatory RNA binding protein. Mol Biol Cell 4:1-5.

Koenig S, Gendelman HE, Orenstein JM, Dal Canto MC, Pezeshkpour GH, Yungbluth M, Janotta F, Aksamit A, Martin MA, Fauci AS (1986) Detection of AIDS virus in macrophages in brain tissue from AIDS patients with encephalopathy. Science 233:1089-1093.

Koh J-Y, Choi DW (1988) Vulnerability of cultured cortical neurons to damage by excitotoxins: differential susceptibility of neurons containing NADPH-diaphorase. J Neurosci 8:2153-2163.

Koh J-Y, Peters S, Choi DW (1986) Neurons containing NADPHdiaphorase are selectively resistant to quinolinate toxicity. Science 234:73-76.

Kolesnikov YA, Pick CG, Ciszewska G, Pasternak GW (1993) Blockade of tolerance to morphine but not to kappa opioids by a nitric oxide synthase inhibitor. Proc Natl Acad Sci USA 90:5162-5166.

Kollegger H, McBean GJ, Tipton KF (1993) Reduction of striatal $N$ methyl-D-aspartate toxicity by inhibition of nitric oxide synthase. Biochem Pharmacol 45:260-264.

Kots AY, Skurat AV, Sergienko EA, Bulargina TV, Severin ES (1992) Nitroprusside stimulates the cysteine-specific mono(ADP-ribosylation) of glyceraldehyde-3-phosphate dehydrogenase from human erythrocytes. FEBS Lett 300:9-12.

Kwon NS, Nathan CF, Stuehr DJ (1989) Reduced biopterin as a cofactor in the generation of nitrogen oxides by murine macrophages. J Biol Chem 264:20496-20501.

Kwon NS, Stuehr DJ, Nathan CF (1991) Inhibition of tumor cell ribonucleotide reductase by macrophage-derived nitric oxide. J Exp Med 174:761-768.

Lamas S, Marsden PA, Li GK, Tempst P, Michel T (1992) Endothelial nitric oxide synthase: molecular cloning and characterization of a distinct constitutive enzyme isoform. Proc Natl Acad Sci USA 89: 6348-6352.

Lei SZ, Pan ZH, Aggarwal SK, Chen HSV, Hartman J, Sucher NJ, Lipton SA (1992) Effect on nitric oxide production on the redox modulatory site of the NMDA receptor-channel complex. Neuron 8:1087-1099.

Lepoivre M, Chenais B, Yapo A, Lemaire G (1990) Alterations of ribonucleotide reductase activity following induction of the nitritegenerating pathway in adenocarcinoma cells. J Biol Chem 265:14143.

I ight DB, Schwiebert FM, Karlson KH, Stanton BA (1989) Atrial natriuretic peptide inhibits a cation channel in renal inner medullary collecting duct cells. Science 243:383-385.

Lipton SA (1992) Requirement for macrophages in neuronal injury induced by HIV envelope protein gp120. Neuroreport 3:913-915.

Lipton SA, Sucher NJ, Kaiser PK, Dreyer EB (1991) Synergistic effects of HIV coat protein and NMDA receptor-mediated neurotoxicity. Neuron 7:111-118.

Lipton SA, Choi YB, Pan Z-H, Lei SZ, Vincent Chen H-S, Sucher NJ, Loscalzo J, Singel DJ, Stamler JS (1993) A redox-based mechanism for the neuroprotective and neurodestructive effects of nitric oxide and related nitroso-compounds. Nature 364:626-632.

Liu J, Farmer JD Jr, Lane WS, Friedman J, Weissman I, Schreiber SL (1991) Calcineurin is a common target of cyclophilin-cyclosporin A and FKBP-FK506 complexes. Cell 66:807-815.

Liu J, Albers MW, Wandless TJ, Luan S, Alberg DG, Belshaw PJ, Cohen P, MacKintosh C, Klee CB, Schreiber SL (1992) Inhibition of T cell signalling by immunophilin-ligand complexes correlates with loss of calcineurin phosphatase activity. Biochemistry 31:3896-3901.

Lonart G, Wang J, Johnson KM (1992) Nitric oxide induces neurotransmitter release from hippocampal slices. Eur J Pharmacol 220: 271-272.

Lowenstein CJ, Glatt CS, Bredt DS, Snyder SH (1992) Cloned and expressed macrophage nitric oxide synthase contrasts with brain enzyme. Proc Natl Acad Sci USA 89:6711-6715.

Lowenstein CJ, Alley EW, Raval P, Snowman AM, Snyder SH, Russell SW, Murphy WJ (1993) Macrophage nitric oxide synthase gene: two upstream regions mediate induction by interferon-gamma and lipopolysaccharide. Proc Natl Acad Sci USA 90:9730-9734.

Lustig HS, von Brauchitsch KL, Chan J, Greenberg DA (1992) Ethanol and excitotoxicity in cultured cortical neurons: differential sensitivity if $N$-methyl-D-aspartate and sodium nitroprusside toxicity. J Neurochem 577:343-346.

Lyons CR, Orloff GJ, Cunningham JM (1992) Molecular cloning and functional expression of an inducible nitric oxide synthase from a murine macrophage cell line. J Biol Chem 267:6370-6374.

Mahadik, Sahebarao P (1992) Gangliosides: new generation of neuroprotective agents. In: Emerging strategics in neuroprotection (Malangos PJ, Lal H, eds), pp 187-223. Boston: Birkhaeuser.

Mancv H, Costa E, Wroblcwski JT, Guidotti A (1990) Abusive stimulation of excitatory amino acid receptors: a strategy to limit neurotoxicity. FASEB J 4:2789-2797.

Manzoni O, Bockaert J (1993) Nitric oxide synthase activity endogenously modulates NMDA receptors. J Neurochem 61:368-370.

Marks GS, Brien JF, Nakatsu K, McLaughlin BE (1991) Does carbon monoxide have a physiological function? Trends Pharmacol Sci 12: 185-188.

Marletta MA (1993) Nitric oxide synthase structure and mechanism. J Biol Chem 268:12231-12234.

Marsden PA, Heng HHQ, Scherer SW, Stewart RJ, Hall AV, Shi X-M, Tsui L-C, Schappert KT (1993) Structure and chromosomal localization of the human constitutive endothelial nitric oxide synthase gene. J Biol Chem 268:17478-17488.

Mayer B, John M, Bohme E (1990) Purification of $\mathrm{Ca}^{2+} /$ calmodulindependent nitric oxide synthase from porcine cerebellum. FEBS Lett 277:215-219.

Mayer B, John M, Heinzel B, Werner ER, Wachter H, Schultz G, Bohme E (1991) Brain nitric oxide synthase is a biopterin- and flavincontaining multi-functional oxido-reductase. FEBS Lett 288:187-191.

McDonald LJ, Moss J (1993) Stimulation by nitric oxide of an NAD linkage to glyceraldehyde-3-phosphate dehydrogenase. Proc Natl Acad Sci USA 90:6238-6241.

McGehee DS, Goy MF, Oxford GS (1992) Involvement of the nitric oxide-cyclic GMP pathway in the desensitization of bradykinin responses of cultured rat sensory neurons. Neuron 9:315-324.

McMillan K, Bredt DS, Hirsch DJ, Snyder SH, Clark JE, Masters BSS (1992) Cloned, expressed rat cerebellar nitric oxide synthase contains stoichiometric amounts of heme which binds carbon monoxide. Proc Natl Acad Sci USA 89:11141-11145.

Meldrum B, Garthwaite J (1990) Excitatory amino acid neurotoxicity and neurodegenerative disease. Trends Pharmacol Sci 11:379-387.

Meller ST, Gebhart GF (1993) Nitric oxide (NO) and nociceptive processing in the spinal cord. Pain 52:127-136.

Michel T, Li GK, Busconi L (1993) Phosphorylation and subcellular translocation of endothelial nitric oxide synthase. Proc Natl Acad Sci USA 90:6252-6256.

Moncada C, Lekieffre D, Arvin B, Meldrum B (1992) Effect of NO synthase inhibition on NMDA- and ischaemia-induced hippocampal lesions. Neuroreport 3:530-532.

Munro H (1993) The ferritin genes: their response to iron status. Nutr Rev 51:65-73.

Murphy S, Simmons ML, Agullo L, Garcia A, Feinstein DL, Galea E, Reis DJ, Minc-Golomb D, Schwartz JP (1993) Synthesis of nitric oxide in CNS glial cells. Trends Neurosci 16:323-328.

Murphy TH, DeLong MJ, Coyle JT (1991) Enhanced NAD(P)H: qui- 
none reductase activity prevents glutamate toxicity produced by oxidative stress. J Neurochem 56:990-995.

Nagafuji T, Matsui T, Koide T, Asano T (1992) Blockade of nitric oxide formation by $N$-omega-L-arginine mitigates ischemic brain edema and subsequent cerebral infarction in rats. Neurosci Lett 147:159162.

Nakane M, Mitchell J, Forstermann U, Murad F (1991) Phosphorylation by calcium calmodulin-dependent protein kinase II and protein kinase $\mathrm{C}$ modulates the activity of nitric oxide synthase. Biochem Biophys Res Commun 180:1396-1402.

Nakane M, Schmidt HHHW, Pollock JS, Forstermann U, Murad F (1993) Cloned human brain nitric oxide synthase is highly expressed in skeletal muscle. FEBS Lett 316:175-180.

Nathan C (1992) Nitric oxide as a secretory product of mammalian cells. FASEB J 6:3051-3064.

Nishikawa T, Kirsch JR, Koehler RC, Bredt DS, Snyder SI I, Traystman RJ (1993) Effect of nitric oxide synthase inhibition on cerebral blood flow and injury volume during focal ischemia in cats. Stroke 24:17171724.

Nowicki JP, Duval D, Poignet H, Scatton B (1991) Nitric oxide mediates neuronal death after focal cerebral ischemia in the mouse. Eur J Pharmacol 204:339-340.

Nozaki K, Moskowitz MA, Maynard KI, Koketsu N, Dawson TM, Bredt DS, Snyder SH (1993) Possible origins and distribution of immunoreactive nitric oxide synthase-containing nerve fibers in rat and human cerebral arteries. J Cereb Blood Flow Metab 13:70-79.

O'Dell TJ, Hawkins RD, Kandel ER, Arancio O (1991) Tests of the roles of two diffusible substances in long-term potentiation: evidence for nitric oxide as a possible early retrograde messenger. Proc Natl Acad Sci USA 88:11285-11289.

Ogura T, Yokoyama T, Fujisawa H, Kurashima Y, Esumi H (1993) Structural diversity of neuronal nitric oxide synthase mRNA in the nervous system. Biochem Biophys Res Commun 193:1014-1022.

Palmer RMJ, Ferrige AG, Moncada S (1987) Nitric oxide release accounts for the biological activity of endothelium-derived relaxing factor. Nature 327:524-526.

Pauwels PJ, Leysen JE (1992) Blockade of nitric oxide formation does not prevent glutamate-induced neurotoxicity in neuronal cultures from rat hippocampus. Neurosci Lett 143:27-30.

Peunova N, Enikolopov G (1993) Amplification of calcium-induced gene transcription by nitric oxide in neuronal cells. Nature 364:450 453.

Pollock JS, Forstermann U, Mitchell JA, Warner TD, Schmidt HHHW, Nakane M, Murad F (1991) Purification and characterization of particulate endothelium-derived relaxing factor synthase from cultured and native bovine aortic endothelial cells. Proc Natl Acad Sci USA 88:10480-10484.

Porter TD, Kasper CB (1985) Coding nucleotide sequence of rat NADPH-cytochrome P-450 oxidoreductase cDNA and identification of flavin-binding domains. Proc Natl Acad Sci USA 82:973-977.

Prabhakar NR, Agani FH, Dinerman JL, Snyder SH (1993) Endogenous carbon monoxide (CO) and carotid body sensory activity. Soc Neurosci Abstr 19:1402.

Prado R, Watson BD, Kuluz J, Dietrich WD (1992) Endotheliumderived nitric oxide synthase inhibition. Effects on cerebral blood flow, pial artery diameter, and vascular morphology in rats. Stroke 23:1118-1124.

Radi R, Beckman JS, Bush KM, Frceman BA (1991a) Peroxynitriteinduced membrane lipid peroxidation: the cytotoxic potential of superoxide and nitric oxide. Arch Biochem Biophys 288:481-487.

Radi R, Beckman JS, Bush KM, Freeman BA (1991b) Peroxynitrite oxidation of sulfhydryls. The cytotoxic potential of superoxide and nitric oxide. J Biol Chem 266:4244-4250.

Rajfer J, Aronson WJ, Bush PA, Dorey FJ, Ignarro LJ (1992) Nitric oxide as a mediator of the corpus cavernosum in response to nonadrenergic noncholinergic transmission. N Engl J Med 326:90-94.

Regan RF, Renn KE, Panter SS (1993) NMDA neurotoxicity in murine cortical cell cultures is not attenuated by hemoglobin or inhibition of nitric oxide synthesis. Neurosci Lett 153:53-56.

Reif DW (1993) Delayed production of nitric oxide contributes to NMDA-mediated neuronal damage. Neuroreport 4:566-568.

Rcif DW, Simmons RD (1990) Nitric oxide mediatcs iron relcase from ferritin. Arch Biochem Biophys 283:537-541.

Rengasamy A, Johns RA (1993) Regulation of nitric oxide synthase by nitric oxide. Mol Pharmacol 44:124-128.

Rettori M, Gimeno M, Lyson K, McCann SM (1992) Nitric oxide mediates norepinephrine-induced prostaglandin E2 release from the hypothalamus. Proc Natl Acad Sci USA 89:11543-1 1546.

Salvemini D, Misko TP, Masferrer JL, Seibert K, Currie MG, Needleman $P$ (1993) Nitric oxide activates cyclooxygenase enzymes. Proc Natl Acad Sci USA 90:7240-7244.

Sandberg K, Berry CJ, Eugster E, Rogers TB (1989a) A role for cGMP during tetanus toxin blockade of acetylcholine release in the rat pheochromocytoma (PC12) cell lines. J Neurosci 9:3946-3954.

Sandberg K, Berry CJ, Rogers TB (1989b) Studies on the intoxication pathway of tetanus toxin in the rat pheochromocytoma (PC12) cell line. J Biol Chem 264:5679-5686.

Schmidt HHW, Pollock JS, Nakane M, Gorsky LD, Forstermann U, Murad F (1991) Purification of a soluble isoform of guanylyl cyclaseactivating-factor synthase. Proc Natl Acad Sci USA 88:365-369.

Schmidt HH, Gagne GD, Nakane M, Pollock JS, Miller MF, Murad F (1992a) Mapping of neural nitric oxide synthase in the rat suggests frequent co-localization with NADPH diaphorase but not with soluble guanylyl cyclase, and novel paraneural functions for nitrinergic signal transduction. J Histochem Cytochem 90:1439-1456.

Schmidt HH, Smith RM, Nakane M, Murad F (1992b) $\mathrm{Ca}^{2+} / \mathrm{cal}-$ modulin-dependent NO synthase type I: a biopteroflavoprotein with $\mathrm{Ca}^{2+} /$ calmodulin-independent diaphorase and reductase activities. Biochemistry 31:3243-3249.

Schuman EM, Madison DV (1991) The intercellular messenger nitric oxide is required for long-term potentiation. Science 254:1503-1506.

Schweizer FE, Wendland B, Ryan TA, Nakane M, Murad F, Scheller RH, Tsien RW (1993) Evidence for the presence of nitric oxide synthase in rat hippocampal pyramidal cells. Soc Neurosci Abstr 19: 241.

Sessa WC, Harrison JK, Barber CM, Zeng D, Durieux ME, D'Angelo DD, Lynch KR, Peach MJ (1992) Molecular cloning and expression of a cDNA encoding endothelial cell nitric oxide synthase. J Biol Chem 267:15274-15276.

Shiga Y, Onodera H, Matsuo Y, Kogure K (1992) Cyclosporin A protects against ischemia-reperfusion injury in the brain. Brain Res 595:145-148.

Skaper SD, Leon A (1992) Monosialogangliosides, neuroprotection, and neuronal repair processes. J Neurotrauma 9:S506-S516.

Snipes GJ, Costello B, McGuire CB, Mayes BN, Bock SS, Norden JJ, Freeman JA (1987) Regulation of specific neuronal and nonneuronal proteins during development and following injury in the rat central nervous system. Prog Brain Res 71:155-175.

Solodkin A, Traub RJ, Gebhart GF (1992) Unilateral hindpaw inflammation produces a bilateral increase in NADPH-diaphorase histochemical staining in the rat lumbar spinal cord. Neuroscience 51: 495-499.

Stamler JS, Simon DI, Osborne JA, Mullins ME, Jaraki O, Michel T, Singel DJ, Loscalzo J (1992a) S-nitrosylation of proteins with nitric oxide: synthesis and characterization of biologically active compounds. Proc Natl Acad Sci USA 89:444-448.

Stamler JS, Singel DJ, Loscalzo J (1992b) Biochemistry of nitric oxide and its redox-activated forms. Science 258:1898-1902.

Steiner JP, Dawson TM, Fotuhi M, Glatt CE, Snowman AM, Cohen N, Snyder SH (1992) High brain densities of the immunophilin FKBP colocalized with calcineurin. Nature 358:584-587.

Stevens CF, Wang Y (1993) Reversal of long-term potentiation by inhibitors of haem oxygenasc. Naturc 364:147-148.

Stuehr DJ, Ikeda-Saito M (1992) Spectral characterization of brain and macrophage nitric oxide synthases. Cyctochrome P-450-like heme proteins that contain a flavin seniquinone radical. J Biol Chem 267: 20547-20550.

Stuehr DJ, Gross SS, Sukuma I, Levi R, Nathan CF (1989) Activated murine macrophages secrete a metabolite of arginine with the bioactivity of endothelium-derived relaxing factor and the chemical reactivity of nitric oxide. J Exp Med 169:1011-1020.

Stuehr DJ, Cho HJ, Kwon NS, Weise MF, Nathan CF (1991a) Purification and characterization of the cytokine-induced macrophage nitric oxide synthase: an FAD- and FMN-containing flavoprotein. Proc Natl Acad Sci USA 88:7773-7777.

Stuehr DJ, Kwon NS, Nathan CF, Griffith OW (1991b) Nw-hydroxy$\mathrm{L}$-arginine is an intermcdiate in the biosynthesis of nitric oxidc from L-arginine. J Biol Chem 266:6259-6263.

Sun Y, Rotenberg MO, Maines MD (1990) Developmental expression of heme oxygenase isozymes in rat brain. Two $\mathrm{H0-2}$ mRNAs are detected. J Biol Chem 265:8212-8217. 
Swanson SK-H, Born T, Zydowsky LD, Cho H, Chang HY, Walsh CT, Rusnak F (1992) Cyclosporin-mediated inhibition of bovine calcineurin by cyclophilins A and B. Proc Natl Acad Sci USA 89:37413745.

Tamura Y, Sato Y, Akaike A, Shiomi H (1992) Mechanisms of cholecystokinin-induced protection of cultured cortical neurons against $\mathrm{N}$-methyl-D-aspartate receptor-mediated glutamate cytotoxicity. Brain Res 592:317-325.

Tayeh MA, Marletta MA (1989) Macrophage oxidation of L-arginine to nitric oxide, nitrite, and nitrate. J Biol Chem 264:19654-19658.

Thomas E, Pearse AGE (1961) The fine localization of dehydrogenases in the nervous system. Histochemistry 2:266-282.

Thomas E, Pearse AGE (1964) The solitary active cells. Histochemical demonstration of damage-resistant nerve cells with a TPN-diaphorase reaction. Acta Neuropathol (Berl) 3:238-249.

Toda N, Ayajiki K, Okamura T (1993) Cerebroarterial relaxations mediated by nitric oxide derived from endothelium and vasodilator nerve. J Vasc Res 30:61-67.

Tottrup A, Svane D, Forman A (1991) Nitric oxide mediating NANC inhibition in opossum lower esophageal sphincter. Am J Physiol 260: G385-G389.

Trifiletti RR (1992) Neuroprotective effects of Ns-nitro-L-arginine in focal stroke in the 7-day old rat. Eur J Pharmacol 218:197-198.

Uemura Y, Kowall NW, Beal MF (1990) Selective sparing of NADPHdiaphorase-somatostatin-neuropeptide $\mathrm{Y}$ neurons in ischemic gerbil striatum. Ann Neurol 27:620-625.

Vanderwinden JM, Mailleux P, Schiffmann SN, Venderhaeghen JJ, De Laet MH (1992) Nitric oxide synthase activity in infantile hypertrophic pyloric stenosis. N Engl J Med 327:511-515.

Verge VMK, Xu Z, Xu X-J, Wiesenfeld-Hallin Z, Hokfelt T (1992) Marked increase in nitric oxide synthase mRNA in rat dorsal root ganglia after peripheral axotomy: in situ hybridization and functional studies. Proc Natl Acad Sci USA 89:11617-11621.

Verma A, Hirsch DJ, Glatt CE, Ronnett GV, Snyder SH (1993) Carbon monoxide, a putative neural messenger. Science 259:381-384.

Vige X, Carreau A, Scatton B, Nowicki JP (1993) Antagonism by NGnitro-L-arginine of L-glutamate-induced neurotoxicity in cultured neonatal rat cortical neurons. Prolonged application enhances neuroprotective efficacy. Neuroscience 55:893-901.

Vincent SR, Kimura H (1992) Histochemical mapping of nitric oxide synthase in the rat brain. Neuroscience 46:755-784.

Vincent SR, Johansson O, Hokfelt T, Skirboll L, Elde RP, Terenius L, Kimmel J, Goldstein M (1983) NADPH-diaphorase: a selective histochemical marker for striatal neurons containing both somatostatin- and avian pancreatic polypeptide (APP)-like immunoreactivities. J Comp Neurol 21 7:252-263.

Vizzard MA, Erdman SL, de Groat WC (1993) The effect of rhizotomy on NADPH diaphorase staining in the lumbar spinal cord of the rat. Brain Res 607:349-353.

Wallis RA, Panizzon K, Wasterlain CG (1992) Inhibition of nitric oxide synthase protects against hypoxic neuronal injury. Neuroreport 3:645-648.

Watkins BA, Dorn HH, Kelly WB, Armstrong RC, Potts BJ, Michaels F, Kufta CV, Dubois-Dalcq M (1990) Specific tropism of HIV-1 for microglial cells in primary human brain cultures. Science 249 549-553.

Weiss G, Goossen B, Doppler W, Fuchs D, Pantopoulos K, WernerFelmayer G, Wachter H, Hentze MW (1993) Translational regulation via iron-responsive elements by the nitric oxide/NO-synthase pathway. EMBO J 12:3651-3657.

White LA, Marletta MA (1992) Nitric oxide synthase is a cytochromeP-450 like hemoprotein. Biochemistry 31:6627-6631.

Wink DA, Kasprzak KS, Maragos CM, Elespuru RK, Misra M, Dunams TM, Cebula TA, Koch WH, Andrews AW, Allen IS, Keefer LK (1991) DNA deaminating ability and genotoxicity of nitric oxide and its progenitors. Science 254:1001-1003.

Wu W (1993) Expression of nitric-oxide synthase (NOS) in injured CNS neurons as shown by NADPH diaphorase histochemistry. Exp Neurol 120:153-159.

Wu W, Ljuzzi FJ, Schinco FP, Dawson TM, Snyder SH (1993) Induction of nitric oxide synthase (NOS) in spinal motoneurons and glia by avulsion injury. Soc Neurosci Abstr 19:440.

Xie Q-W, Cho HJ, Calaycay J, Mumford RA, Swiderek KM, Lee TD, Ding A, Troso T, Nathan C (1992) Cloning and characterization of inducible nitric oxide synthase from mouse macrophages. Science 256:225-228

Xie QW, Whisnant R, Nathan C (1993) Promoter of the mouse gene encoding calcium-independent nitric oxide synthase confers inducibility by interferon gamma and bacterial lipopolysaccharide. J Exp Med 177:1779-1784.

Xu W, Charles IG, Moncada S, Gorman P, Sheer D, Liu L, Emson P (1993) Mapping of the genes encoding human inducible and endothelial NOS to the pericentric region of chromosome 17 and to chromosome 7 respectively. Gene, in press.

Yamamoto R, Bredt DS, Snyder SH, Stone RA (1993) The localization of nitric oxide synthase in the rat eye and related cranial ganglia. Neuroscience 54:189-200.

Yamamoto S, Golanov EV, Berger SB, Reis DJ (1992) Inhibition of nitric oxide synthesis increases focal ischemic infarction in rat. J Cereb Blood Flow Metab 12:717-726.

Yui Y, Hattori R, Kosuga K, Eizawa H, Hiki K, Kawai C (1991) Calmodulin-independent nitric oxide synthase from rat polymorphonuclear neutrophils. J Biol Chem 266:12544-12547.

Zhang J, Snyder SH (1992) Nitric oxide stimulates auto-ADP-ribosylation of glyceraldehyde-3-phosphate dehydrogenase in brain. Proc Natl Acad Sci USA 89:9382-9385.

Zhang J, Dawson VL, Dawson TM, Snyder SH (1994) Nitric oxide activation of poly (ADP-ribose) synthetase in neurotoxicity. Science 263:687-689.

Zhang ZG, Chopp M, Zaloga C, Pollock JS, Forstermann U (1993) Cerebral endothelial nitric oxide synthase expression after focal cerebral ischemia in rat. Stroke 24:2016-2021.

Zhu X-Z, Luo L-G (1992) Effect of nitroprusside (nitric oxide) on endogenous dopamine release from rat striatal slices. J Neurochem 59:932-935.

Zhuo M, Small SA, Kandel ER, Hawkins RD (1993) Nitric oxide and carbon monoxide produce activity-dependent long-term synaptic enhancement in hippocampus. Science 260:1946-1950. 